\title{
The effects of the introduction of tax incentives on retirement saving
}

\author{
Juan Ayuso ${ }^{1}$. Juan F. Jimeno ${ }^{2,3,4}$. Ernesto Villanueva ${ }^{2}$ (D)
}

Received: 12 February 2019 / Accepted: 11 June 2019 / Published online: 4 July 2019

(c) The Author(s) 2019

\begin{abstract}
We examine the incidence on household consumption of the introduction of tax incentives to retirement saving. First, using data from a panel of tax returns we document that most contributions to pension funds are by older/high-income individuals. Then we use panel data from a consumption survey spanning the period 1985 and 1991 to find that there is substantial heterogeneity in the response of household saving to tax incentives. While the overall amount of new saving we estimate is limited (at most 19 cents per euro contributed on average), saving responses differ substantially across age groups: among the group of households between 56 and 65 years of age, the group that most actively contributed to the plan, there are very small consumption changes; among the group of households between 46 and 55 years of age, the decrease in (mostly durable) consumption expenditures is much larger.
\end{abstract}

Keywords Pension funds · Tax incentives · Saving

JEL Classification D14 $\cdot$ H24 $\cdot$ H55

\begin{abstract}
First version: August 2007. We thank the comments and insights from Jerô me Adda, Miguel Almunia, Manuel Arellano, Olympia Bover, Tom Crossley, Tom de Leire, Brigitte Madrian, Giovanni Mastrobuonni, Fernando Restoy and two anonymous referees. We gratefully acknowledge the help of Cesar Perez and the personnel at the Instituto de Estudios Fiscales both with the Panel of Tax Returns and for providing us with information of the age of tax filers. Pedro Albarrán was very helpful in providing us with code to read the ECPF. We also thank participants at the Universitat Pompeu Fabra, Simposio de Analisis Economico, EEA Meetings in Budapest, the Workshop "Saving for Retirement: Too Little, Too Late" at OENB, and the SERIES Special Issue on Taxes and Transfers at Banco de España. All views and opinions are our own, and not necessarily those of Banco de España or the Eurosystem.
\end{abstract}

$凶$ Ernesto Villanueva

ernesto.villanueva@bde.es

1 DG Operations, Markets and Payment Systems, Banco de España, Alcala 48, 28014 Madrid, Spain

2 DG Economics and Statistics, Banco de España, Alcala 48, 28014 Madrid, Spain

3 CEPR, London, UK

4 IZA, Bonn, Germany 


\section{Introduction}

Tax incentives of retirement saving are present in many countries as a mean to achieve that individuals accumulate sufficient wealth for retirement, either by promoting total savings or by changing the composition of wealth portfolios giving more weight to "long-run" savings (pension plans), less liquid and, thus, less likely to be used before retirement. The rationale for those incentives is that financial planning for retirement is a complex task, with little room to make adjustments once the individual has decided to retire. ${ }^{1}$

Contributions to pension plans increase with tax incentives, particularly among individuals with age close to retirement and facing high-income tax rates. ${ }^{2}$ However, the extent to which tax incentives rise retirement savings is a controversial issue. In the USA, contributions to IRAs and 401(k) plans are considered as net additions to saving for some authors (see, for instance, Poterba et al. 1995, 1996; Gelber 2011), while others conclude that tax incentives of retirement savings have a strong effect on the allocation of saving and wealth, but little or not effect on the level (see, for instance, Gale and Scholz 1994; Engen et al. 1996, and Attanasio et al. 2004). ${ }^{3}$ For other countries, studies mostly point at a limited impact of tax incentives on either contributions or wealth. ${ }^{4}$

Three problems make it very difficult to identify the effects of tax incentives on savings: (i) the wide heterogeneity in the individual responses to tax incentives, as these responses depend on variables like age, the existence of liquidity constraints or the degree of patience, (ii) the lack of microeconomic data on consumption, saving, and wealth to observe the wide range of financial and personal characteristics determining marginal tax rates, earnings volatility, pension wealth, discount and interest rates, together with individual-/household-level information on income, wealth and its composition, and (iii) the differential impact that tax incentives may have at the moment when they are introduced with respect a situation in which they have been

\footnotetext{
1 See Thaler (2016). The literature on whether or not households save enough for retirement is too large to be summarized here. An indicator of poor financial planning for retirement is the fall of expenditure around retirement-see (Bernheim et al. 2001). Luengo-Prado and Sevilla (2013) document that expenses in food at home fall by $8 \%$ among Spanish households whose head retired between 2001 and 2004, the most recent cohorts in their sample. However, these authors do not interpret that the fall can be entirely attributed to poor financial planning.

2 Engelhardt and Kumar (2007) find that contributions increase with employer matching rates in 401(k) the USA. Duflo et al. (2006) conduct a field experiment where randomly manipulated matching rates increase take-up among low-income savers - in a setting where those incentives are salient. However, Beshears et al. (2017) document that US employees are confused about the tax incentives of several tax-favored products on the USA, and their contributions to tax-favored products are unresponsive to changes in their tax treatment.

3 See the surveys by Hawksworth 2006 and (Bernheim 2002). Chernozhukov and Hansen (2004) find that the heterogeneity can be due to a heterogeneous impact at different points of the wealth distribution, as tax incentives may increase wealth at the lower deciles but not at the top.

4 We discuss below the important study by Chetty et al. (2014), for Denmark. They find that savers do not react much to changes in tax incentives. See Milligan (2002) and Veall (2001) on Canada, Blundell et al. (2006) and Chung et al. (2006) on the UK, and Jappelli and Pistaferri (2002) on Italy. Those studies mostly focus on the impact of tax incentives on portfolio composition. We also discuss below the evidence in Anton et al. (2014) that points at a limited impact of tax incentives on new saving in Spain. Cross-country regressions point out that the accumulation of pension funds increases national savings only when they are compulsory (López Murphy and Musalem 2004).
} 
operative for a long period, as there may be some gradual adjustment to the desired level of savings and to the optimal wealth composition after the introduction of tax incentives.

In this paper we provide empirical evidence on the impact of tax incentives on saving by examining the effects of the introduction of tax incentives of retirement in Spain in 1988. By using the introduction of the exemption as an arguably exogenous-tothe individual change in incentives to save, our analysis is less affected by problems (i) and (ii) than previous work. Of course, by focusing on the introduction of the exemption, our analysis is affected by problem (iii): we cannot estimate the impact of the exemption when the program has been operative for a long period. However, we describe how contributions to pension plans are distributed in 2014, thirty years after its introduction, and make an admittedly limited discussion of whether those changes go into the direction of generating more or less new saving.

We analyze the impact of the introduction of these tax incentives in two steps. First, we use a panel of tax returns to identifying the population groups who most used these incentives. Second, we use a panel of household consumption to estimate the impact of tax incentives on consumption/saving of different population groups. Our paper contributes to the literature on tax incentives to save in two different ways.

First, we are able to use data spanning the periods before and after the introduction of tax-favored retirement plans. Thus, we are able to observe consumption choices in a situation in which tax incentives are not present. In the absence of a controlled experiment, such as in Duflo et al. (2006), examining the evolution of savings around the introduction of the tax exemption mitigates some of the problems in the analysis of IRAs or $401(\mathrm{k}) \mathrm{s}$ that typically study the impact using post-introduction trends among different groups in the population. In addition, Chetty et al. (2014) show that a substantial share of Danish taxpayers are passive investors that do not react to tax incentives aimed at increasing retirement saving, and that lack of attention limits the effectiveness of programs that depend on voluntary contributions. The introduction of pension plans is a salient event when tax incentives vary abruptly, thus allowing us to examine if investors revise their consumption decisions when changes are sufficiently large.

Second, we focus on the impact of the introduction of the pension plans program on household consumption, rather than on household wealth. While household wealth is a very important outcome, household consumption conveys important information. For example, in the presence of employer contributions, household consumption is more likely to reflect how the flow of active household saving is affected by tax incentives than household wealth (see Chernozhukov and Hansen 2004). Moreover, according to the permanent income model, household wealth is more sensitive to transitory income changes than household consumption (Blundell and Preston 1998). Thus, any analysis that focuses on group-specific changes in household wealth over time faces the problem of disentangling between the impact of tax incentives and the impact of different forms of between-group income or wealth changes. Finally, even studies with comprehensive information on wealth from administrative records like Chetty et al. (2014) have limited information on housing wealth or mortgages. Unfortunately, tax-favored retirement accounts generate incentives to postpone the repayment of mortgage debt and invest in pension plans-see (Amromin et al. 2007). 
Detailed expenditure data permits a direct assessment of whether or not incentives generate new saving.

We extend the insights in Attanasio and De Leire (2002), who infer the impact of tax incentives on new saving by comparing the consumption changes of new contributors to those of old contributors. In a life cycle model, new contributors effectively experience an increase in the return to their saving (i.e., their consumption path is altered by contributing to a pension plan), while previous contributors do not. As they find that old and new contributors have similar consumption growth, they infer that tax incentives do not generate new saving. Anton et al. (2014) apply similar insights to longitudinal Spanish data and find that household expenditure does not fall when households contribute to the program. However, households that choose to start contributing to pension plans are very different from either those that continue to do so. Hence, variation associated with actual contributions may reflect the influence of variables correlated with the incentive to save. ${ }^{5}$ To get around such omitted variables problem, we build a variable that summarizes the incentives to contribute and is arguably less affected by endogeneity biases. Our instrumental variable is the interaction between the income marginal tax rate and the age of the individual at the time of introduction of the exemption. Individuals with higher-income marginal tax rates experiment a higher increase in post-tax returns (Milligan 2002) and age proxies income risk and preference for liquid assets. We check that our variable is indeed a strong predictor of contributions: it was mainly filers in the top quartile of labor earnings who exempted contributions and, within that group, average contributions increased monotonically with age. Using a separate expenditure survey, we then examine whether the consumption growth of broad age groups in the top income quartile, relative to our control group of young households, experienced a drop around the introduction of the exemption.

Our results suggest that there is indeed substantial heterogeneity in the contributions to pension plans and in the response of household saving to tax incentives. While the overall amount of new saving we estimate is limited (around 19 cents per euro contributed on average, not very precisely estimated), saving responses differ substantially across age groups - a finding consistent with previous literature using household wealth. ${ }^{6}$ In particular, we document very small fall in consumption among the group of households between 56 and 65 years of age, the group that most actively contributed to the plan. Instead, we find a larger decrease in consumption expenditures of the group of households between 46 and 55 years of age. We use a simple permanent income model to interpret such pattern of responses. The model predicts that households in the verge of retirement find pension plans and other saving forms as strong substitutes, and tend to exhaust tax-exempted contribution limits by reshuffling their wealth port-

\footnotetext{
5 A first objection by Bernheim (2002) is that the timing of contributions is correlated with saving preferences of the households, and that such differences are hard to detect using consumption growth-a poor indicator of intrinsic thrift according to Bernheim et al. (2001). In addition, Bernheim (2002) and Poterba et al. (1996) also argue that Attanasio and De Leire's (2002) results can be also be re-interpreted as contributions of old contributors representing new saving and those of new contributors representing portfolio reshuffling.

6 See Chernozhukov and Hansen (2004) and Engen and Gale (2000) compare trends in household wealth across individuals that are not eligible for the $401(\mathrm{k}) \mathrm{s}$ and those that are not, and document substantial heterogeneity across income and age groups.
} 
folios. In that case, tax incentives do not generate a meaningful substitution effect. Conversely, groups further away from retirement, with plausibly less accumulated wealth and for whom there is a trade-off between the post-tax return of retirement saving and the illiquidity of the investment, contribution limits are not binding and tax incentives may generate new saving. Actually, data on tax returns confirm those predictions: within the group of individuals with the highest marginal taxes and who were close to retirement, $30 \%$ of tax filers exhausted the contribution limits, while the fraction is three times smaller among younger individuals.

The structure of this paper is as follows. Section 2 provides a description of the main regulation of pension plans in Spain when tax incentives were introduced in 1988. Section 3 contains some theoretical discussion of the factors determining the impact of the introduction of tax incentives on retirement saving. Section 4 discusses the characteristics of the datasets we use and lays out our empirical strategy. Section 5 examines the incidence of contributions across age and income groups, while Sect. 6 presents the main empirical results. Section 7 quantifies the impact of contributions on savings. Section 8 compares the distribution of contributions to pension plans in 2014 to that in 1988-1991, while Sect. 9 contains some concluding remarks.

\section{The introduction of tax incentives of retirement saving in Spain}

In Spain the first piece of legislation regulating private pension plans was not passed until 1987, when the Ley de Planes y Fondos de Pensiones (formally, Ley 8/87) established three types of private pension plans: employment plans (planes de empleo), under which the sponsor is a non-financial firm while its employees are the plan members, associate plans (planes asociados), under which the sponsor is some legal association and the association members are entitled to contribute to the plan, and individual plans (planes individuales), created by financial entities - that act as sponsors - and open to any individual who wants to contribute. Individual pension plans have similar features to post-86 IRAs in the USA.

Contributions to pension plans were exempted from income taxation, up to certain limits. More concretely, contributions below the minimum of $15 \%$ of labor income and half a million pesetas (3005.06 euros) where directly deducted from the income tax base. An additional 15\% of contributions beyond this limit but below 750,000 pesetas (4507.59 euros) was deductible from the income tax quota. It is worth noting that up to 1987, the income tax levied household individual partners jointly. Since 1988 , however, couples may decide whether to be taxed jointly or individually. In the former case (joint income tax return), limits apply to each spouse individually and therefore could even double for households opting for joint income taxation.

Upon redemption, funds were subject to income taxation at different rates depending upon how redemption took place. They were considered non-regular income if received as a single payment and as a regular income when received in the form of annuities. In the first case, $40 \%$ of the payment was exempted from taxation, while in the second case it was taxed at the marginal tax rate on income. As the income tax on non-regular income is lower than that on regular income - in order to correct the distortion created by tax rates that increase with income level when multi-period income accumulates 
in a single year-redemption in the form of a single payment was, in general, much more prevalent.

As in this paper we focus on the effects on household consumption of the introduction of tax incentives of retirement saving, it is important to bear in mind that two other important changes in household income taxation were introduced in 1988. On the one hand, income marginal tax rates were modified, as illustrated in Table 9 in the Appendix. The number of rates was reduced from 34 to 16, and the maximum one was set at 56\%, 10 percentage points less than one year before. Still, our reading of Table 9 in the Appendix is that those changes in marginal income rates for two upper quartiles were rather modest (2\% in the 1987 median and upper quartiles). Also, as commented above, in 1988 household individual partners were allowed to decide whether to pay income taxes individually or jointly. As the income tax was highly progressive, households were both spouses had labor income often opted for individual taxation, something we examine in Sect. 6.3. ${ }^{7}$

\section{Some theoretical framework}

The analysis of tax incentives of retirement saving is typically conducted in an equivalent manner to the rise in the marginal rate of return to saving, specially pronounced for individuals with high marginal tax rate on their income (see Bernheim 2002). The overall impact on saving depends then on substitution, income and wealth effects, whose relative sizes depend on the curvature of the utility function. ${ }^{8}$

To fix ideas, assume that an individual lives for two periods, and derives utility from $c_{1}$, the level of consumption in the first period (working life) and $c_{2}$, in the second period (retirement). Individuals have an initial wealth endowment $A_{0}$ and may save in a risk-free asset $A_{1}$ or a tax-favored vehicle $F_{1}$. Contributions to the fund $F_{1}$ are exempted from the tax base. Individuals receive an stream of income $y_{1}$ (first period) and $y_{2}$, in the second, and face the marginal income taxes $\tau_{1}$ and $\tau_{2}$. The budget constraints can be written as follows

$$
\begin{array}{ll}
\text { 1st period } & c_{1}+A_{1}+F_{1}=y_{1}\left(1-\tau_{1}\right)+\tau_{1} F_{1}+A_{0} \\
\text { 2nd period: } & c_{2}=\left[y_{2}+F_{1}(1+r)+r A_{1}\right]\left(1-\tau_{2}\right)+A_{1}
\end{array}
$$

Given perfect certainty, investing in $F_{1}$ is a preferred to non-tax-favored vehicle $A_{1}$. Assuming momentarily that individuals cannot borrow to invest in $F_{1}\left(A_{1}=0\right)$ and, after consolidating budget constraints:

$$
c_{1}+\frac{\left(1-\tau_{1}\right)}{(1+r)\left(1-\tau_{2}\right)} c_{2}=y_{1}\left(1-\tau_{1}\right)+\frac{1}{(1+r)} y_{2}+A_{0}
$$

\footnotetext{
7 Female labor market participation rates in Spain have traditionally been relatively low, more so for the older population cohorts. Thus, the effects of voluntary joint income tax filing are likely to depend on the age of the household's head. See Sect. 6.3 for an empirical assessment.

8 A sufficient condition for tax incentives to increase retirement savings is that the elasticity of marginal utility is lower than -1 (see, for instance, Attanasio and De Leire 2002).
} 
Thus, tax incentives result in an after-tax gross return to saving in $F_{1}$ of $\frac{(1+r)\left(1-\tau_{2}\right)}{1-\tau_{1}}$. Individuals with higher current marginal tax rates during their working life $\tau_{2}$ and a lower marginal tax rates during retirement $\tau_{2}$ experience a higher return to investing in pension plans. Whether this higher rate generates new saving (i.e., reduces consumption or increases labor supply) depends on the relative strength of substitution vs income effects. Using an isoelastic utility function with curvature parameter $\rho$, consumption during the working life of households that contribute to pension plans can be expressed as follows:

$$
c_{1}=\frac{1}{1+\left[(1+r) \frac{1-\tau_{2}}{1-\tau_{1}}\right]^{\frac{1}{\rho}-1}}\left\{\left[y_{1}\left(1-\tau_{1}\right)\right]+\frac{1}{1+r} y_{2}+A_{0}\right\}
$$

We make two notes about this expression. The first is that tax incentives generate new saving (i.e., diminish first period consumption) as long as $\rho<1$. That is, only in that case individuals with high $\tau_{1}$ diminish consumption (the substitution effect generated by the lower price of consumption in the second period is strong enough to compensate the income effect). The second note is that in a world without tax incentives - such as Spain prior to 1987-the post-tax return on saving diminishes with the marginal tax. Hence, the introduction of tax incentives leads individuals to revise their consumption plans and diminish consumption growth.

\subsection{Liquidity}

A key feature of retirement accounts is that the funds accumulated are inaccessible during the working life. While the previous considerations may still hold for individuals close enough to retirement age — as funds remain illiquid for a short period of time-workers in their prime age face uncertainty about future income and may optimally choose to allocate a fraction of their savings into a liquid, non-tax-favored asset (see Gale and Scholz 1994 or Chetty et al. 2014). In principle, holding retirement age constant, current age is an exogenous indicator of the demand for liquid assets. Given that source of heterogeneity in the incentive to contribute to pension plans, we present separate estimates by age group.

\subsection{Contribution limits and borrowing constraints}

As it is the case in other tax systems, there is a maximum amount that is tax exempt in Spain (even though there was no limit to the amount that could be contributed to a pension plan at the time of introduction). In that case, the budget constraint becomes

$$
\begin{array}{lc}
\text { 1st period } & c_{1}+A_{1}+F_{1}=y_{1}\left(1-\tau_{1}\right)+\tau_{1} \min \left(F_{1}, \bar{F}\right)+A_{0} \\
\text { 2nd period: } & c_{2}=\left[y_{2}+F_{1}(1+r)+r A_{1}\right]\left(1-\tau_{2}\right)+A_{1}
\end{array}
$$

Note $F_{1}$ can still be a preferred saving choice (compared to $A_{1}$ ), as long as $F_{1}$ is below $\bar{F}$. However, once the limit is reached, households are indifferent between 
investing in the non-tax-favored saving vehicle $A_{1}$ or continue investing in $F_{1}$ at the market return $r$ In either case, once individuals exceed the contribution limit $\bar{F}$, the return to additional saving does not vary with the marginal tax, which shuts down the substitution effect and, according to the life cycle model, the possibility of generating new saving. Hence, the fraction of contributors that exhaust the contribution limit $\bar{F}$ is informative about the generation of new saving. Groups that exhaust the contribution limit should experience no falls in consumption around the introduction of tax incentives.

A related, but separate issue is the presence of borrowing constraints. As mentioned above, there is an incentive to borrow at the risk-free rate $r$ to save at the tax-favored rate $(1+r) \frac{1-\tau_{2}}{1-\tau_{1}}$. The model sketched above precludes that possibility by forcing $A_{1}$ to be positive. However, in many instances, borrowing constraints are not as tight as in the model above. For example, Amromin et al. (2007) show that the US tax code makes it profitable to defer advance mortgage payments to contribute to IRAs, a tax-favored retirement vehicle. The possibility of borrowing increases the incentive to contribute to pension plans up to the contribution limit $\bar{F}$ for those individuals facing high marginal income taxes. In the empirical part, we examine the degree of accumulation of contributions at the limit to infer the possibility of tax arbitrage.

\subsection{Summary}

Following these considerations, we characterize the impact of tax incentives of retirement savings on contributions to pension plans and household expenditure using groups defined on the basis of their age (as a proxy for liquidity) and income (as a mechanical correlate of marginal taxes).

First, we examine the probability of contributing to pension plans and the amount contributed by focusing on working-age individuals at the top of the income distribution - as they face the highest income marginal tax rates. We regard individuals between 20 and 35 years when tax incentives were introduced as the least likely to have accumulated wealth and find pension plans less attractive for liquidity reasons (see Gale and Scholz 1994 for a similar reasoning). We expect contributions to pension plans from individuals aged 20-35 years of age and to be low, while they should increase with age. A first indicator of whether tax incentives generate new saving examines the fraction of contributors that bunch at the maximum contribution level. According to a life cycle model, contributors at the maximum do not really experience an increase in the marginal return to saving (which is the pre-tax interest rate) but do experience a positive wealth effect.

As for impact on consumption, we expect to find a larger consumption drop among medium-age individuals with high marginal income tax. For these individuals incentives for contributing to pension plans are largest, as income and marginal tax rates on income are at their peaks, and uncertainty and liquidity considerations are less important than for younger individuals. Also, for that population group, accumulated wealth is not at its highest, so that reshuffling under borrowing constraints cannot be too large, and contributions to pension plans need to arise from lower consumption. Finally for individuals close to retirement wealth is higher and liquidity considerations are even 
less relevant, so that contributions are more likely and to arise from reshuffling of the wealth portfolio than from higher saving.

\section{Data sets and empirical strategy}

We use two data sets. The first is a panel of tax returns filed by individuals between 1982 and 1998, put together by the Instituto de Estudios Fiscales, in collaboration with the Spanish Tax Agency. The second is a detailed household expenditure panel survey.

\subsection{The panel of income tax returns}

In 1987 the Instituto de Estudios Fiscales sampled 1 in 25 tax returns in 48 out of the 52 Spanish provinces, and then tracked back the returns of those filers from 1982 and forward until 1998. ${ }^{9}$ To maintain the representativeness of the sample, the tax authority also added in each year after 1988 a refreshment sample with new tax returns. The sample contains each year all the information contained in a tax return (i.e., all taxable income sources and all tax deductions but excludes all information that can threat anonymity). While the original sample did not contain the age of the main filer, the tax authority subsequently collected the age of a filer in the household for $70 \%$ of the 1987 sample. Due to compulsory joint filing in the year in which the sample was made, the Statistical Agency was able to identify pre-1988 "fiscal households" and then keep track of the tax returns filed by each member of the original 1987 couple-even if married filers opted for filing separately in a particular year.

We use as the unit of our analysis the "fiscal household" (i.e., the 1987 tax filing unit), focusing in variables such as the yearly income of the 1987 tax filing unit and household characteristics (marital status and the number of children below 18 years). ${ }^{10}$ After 1988, we aggregate at the household level the individual and employer contributions to pension plans, but nothing substantially changes when we exclude employer contributions, which represented a very small fraction of the total in the immediate years after the introduction of the tax incentives.

Our main goal with this information is to identify who contributes and to quantify the mean contribution by age and income groups. Thus, our analysis focuses on the subsample of the tax return panel containing the age of the main filer between 1988 and 1991. The reason to focus on those specific years is that one should only observe a fall in expenditure when households start contributing and presumably adjust their savings plan in response to the introduction of tax incentives. After that first contribution period, the life cycle hypothesis predicts that, holding other variables constant, individuals who face higher return to their saving tend to delay consumption to the

\footnotetext{
9 Due to a special tax regime, the Basque Country and Navarra, which represent about $5 \%$ of the Spanish population, were not covered.

10 We have dropped the contributions to pension funds by tax filers who report self-employed income, since in this case reported income could be subject to serious measurement bias.
} 
future, so expenditure growth should be positive. ${ }^{11}$ Thus, using further years would confound the effect of new contributors (who may cut their expenditure and have negative expenditure growth) and existing contributors (who increase their consumption over time). Additionally, in 1992 there was a further reform on the tax treatment of the exemption, with confounding impacts on consumption growth. Hence, we examine the period 1985-1991, as the 1988-1991 is when we observe many new filers starting to contribute.

The evolution of the fraction of "fiscal households" with at least one contributor to pension plans is shown in Table 1, Panel A, column 1. While initially low, the fraction of contributors rapidly increased, and at the end of the 1990 s some $24 \%$ of "fiscal households" had made a contribution. Possibly because contributors in 1988 reported higher incomes than contributors who did their initial contribution after that year, the mean and median contribution declined in real terms from 1337 euros in 1988 (Table 1, Panel A, column 2, first row), about $6 \%$ of the gross labor income reported by filers who contributed, to 1191 euros in 1998 (Panel A, column 2, last row of Table 1). As we discuss below, the vast majority of contributions (70\%) were made by filing units that reported gross labor income in the top quartile of the income distribution. Contributions in the high end of the income distribution were relatively persistent: $81 \%$ of contributors who were in the top income quintile in 1988 and started contributing would contribute on the following year, and the average number of contributions over a 6-year period was 5.04 (see Table 10 in the Appendix).

Panel B of Table 1 shows the summary statistics of the subsample used for the analysis. The mean gross labor income reported by the tax unit was 13,974 euros. The (unconditional) average contribution is 65.7 euros with $5 \%$ of tax units actually making a contribution. The mean age of the main filer is 41 years.

\subsection{The household expenditure survey (ECPF)}

The second sample uses the 1985-1991 waves of a quarterly expenditure survey called Encuesta Continua de Presupuestos Familiares (henceforth, ECPF). ${ }^{12}$ The ECPF interviews some 3000 households in each wave. Households are handed a notebook to record their expenses on food, transportation, textiles, health and schooling during some weeks of the quarter. Also, households report retrospective information about more bulky purchases, like furniture, cars, electronic goods (TV, and others) and white goods (washing machines, dishwashers, fridges). Respondent households are tracked during eight quarters (at most), and report information about household composition and the income received by each household member, with some disaggregation on net-of-tax income sources. We focus on households headed by an individual who is a married employee.

Ideally, the key variables in our analysis would be total household expenditures and the household-specific marginal taxes to labor income. However, while we make some use of the income marginal tax rates, not directly observed in this survey, most of our

\footnotetext{
11 See Attanasio and De Leire (2002) who discuss this point in detail.

12 See Collado and Browning (2007), Carrasco et al. (2005) and Albarrán (2004) for recent uses of the ECPF to test theories of consumption behavior.
} 
Table 1 Summary statistics of panel of tax returns

\begin{tabular}{|c|c|c|c|c|c|c|}
\hline $\begin{array}{l}(1) \\
\text { Year }\end{array}$ & $\begin{array}{l}\text { (2) } \\
1 \text { if contributes }\end{array}$ & $\begin{array}{l}\text { (3) } \\
\text { Mean (if nonzero) }\end{array}$ & \multicolumn{2}{|l|}{ (4) } & $\begin{array}{l}(5) \\
\text { 10th perc. }\end{array}$ & (6) \\
\hline \multicolumn{7}{|c|}{ Panel A: The incidence of contributions to "pension funds" and amounts } \\
\hline 1988 & 0.024 & 1.337 & \multicolumn{2}{|l|}{0.760} & 0.137 & 3.012 \\
\hline 1989 & 0.036 & 1.197 & \multicolumn{2}{|l|}{0.679} & 0.127 & 2.829 \\
\hline 1990 & 0.053 & 1.121 & \multicolumn{2}{|l|}{0.636} & 0.141 & 2.683 \\
\hline 1991 & 0.073 & 1.174 & \multicolumn{2}{|l|}{0.609} & 0.149 & 3.057 \\
\hline 1992 & 0.107 & 1.047 & \multicolumn{2}{|l|}{0.563} & 0.086 & 2.652 \\
\hline 1993 & 0.128 & 1.081 & \multicolumn{2}{|l|}{0.572} & 0.091 & 2.801 \\
\hline 1994 & 0.138 & 1.054 & \multicolumn{2}{|l|}{0.514} & 0.085 & 2.844 \\
\hline 1995 & 0.162 & 1.130 & \multicolumn{2}{|l|}{0.564} & 0.082 & 3.064 \\
\hline 1996 & 0.172 & 1.119 & \multicolumn{2}{|l|}{0.548} & 0.088 & 2.950 \\
\hline 1997 & 0.210 & 1.117 & \multicolumn{2}{|l|}{0.561} & 0.095 & 2.889 \\
\hline 1998 & 0.246 & 1.191 & \multicolumn{2}{|l|}{0.570} & 0.099 & 3.157 \\
\hline & & & Mean & SD & Min. & Max. \\
\hline \multicolumn{7}{|c|}{ Panel B: Characteristics of 1988-1991 sample } \\
\hline \multicolumn{3}{|c|}{ Contribution to pension funds } & 0.066 & 0.402 & 0 & 750 \\
\hline \multicolumn{3}{|c|}{ Fraction who contribute } & 0.0535 & 0.225 & 0 & 1 \\
\hline \multicolumn{3}{|c|}{ Contribution/gross earnings (if positive) } & 0.063 & 0.072 & 0.001 & 0.4 \\
\hline \multicolumn{3}{|c|}{ Household pre-tax earnings } & 13.974 & 0.010 & 3.704 & 1012 \\
\hline \multicolumn{3}{|c|}{ 4-Quarter change, labor earnings } & 0.888 & 3.701 & -0.263 & 465.89 \\
\hline \multicolumn{3}{|c|}{ Family size (excluding adults above 18 years) } & 3.374 & 1.13 & 2 & 12 \\
\hline \multicolumn{3}{|l|}{ Age } & 41.25 & 11.06 & 20 & 65 \\
\hline
\end{tabular}

Sample size: 122,531

1. All monetary magnitudes in 1000 s of euro (constant prices of 1987)

2. Sample used in Panel A: 1988-1998 panel of tax returns. We only include contributions made by tax units with a filer between 20 and 65 years of age that do not report self-employed income. Contributions include both employer and individual contributions and are aggregated at the level of 1987 fiscal unit (in 1987 couples had to file income taxes jointly)

3. Sample used in Panel B: All filers between 20 and 65 years who do not report self-employment or professional income, between 1988 and 1991. Contributions include those made by the employer and are aggregated at the level of the 1987 fiscal unit

analyses focus on dummies based on the quartile of pre-tax income, and concentrate on the top two quartiles of the income distribution. We obtained yearly pre-tax income by applying the withholding tax rates and adding contributions to the post-tax income reported in the ECPF (see Appendix Tables 9, 10 for details). Regarding household expenditure, we have little priors on how specific household consumption components react to changes in tax incentives. Thus, and following Attanasio and Brugiavini (2003), we include basically all consumption components (including the expenditure in all durable goods, but housing) and present results separately by type of good. The main characteristics of the samples used are shown in Tables 2 (all households) and 3 (the top two quartiles of the income distribution). 
Table 2 Summary statistics, expenditure survey (ECPF)

\begin{tabular}{|c|c|c|c|c|c|c|c|c|}
\hline & \multirow[t]{2}{*}{ Mean } & \multirow[t]{2}{*}{ SD } & \multirow[t]{2}{*}{ Min. } & \multirow[t]{2}{*}{ Max. } & \multicolumn{2}{|c|}{$\underline{1985.1-1986.4}$} & \multicolumn{2}{|c|}{ 1987.1-1990.4 } \\
\hline & & & & & Mean & SD & Mean & $\mathrm{SD}$ \\
\hline Quarterly total expenditure & 2.135 & 1.640 & 0.112 & 35.245 & 1.922 & 1.306 & 2.201 & 1.725 \\
\hline $\begin{array}{l}\text { Quarterly } \\
\text { expenditure-periodified }\end{array}$ & 2.084 & 1.384 & 0.112 & 14.344 & 1.872 & 1.174 & 2.149 & 1.437 \\
\hline $\begin{array}{l}\text { 4-Quarter change of log of } \\
\text { expenditure }\end{array}$ & 0.016 & 0.55 & -1.99 & 1.99 & 0.009 & 0.544 & 0.0259 & 0.553 \\
\hline $\begin{array}{l}\text { 4-Quarter change of level of } \\
\text { periodified expenditure }\end{array}$ & 0.072 & 0.50 & -1.99 & 1.99 & 0.043 & 0.52 & 0.081 & 0.50 \\
\hline $\begin{array}{l}\text { Household pre-tax annual } \\
\text { earnings }\end{array}$ & 9951 & 5.458 & 0.914 & 81.980 & 8.266 & 4.506 & 10.473 & 5.619 \\
\hline $\begin{array}{l}\text { 4-Quarter change in yearly } \\
\text { log earnings }\end{array}$ & 0.048 & 0.18 & -1.463 & 2.58 & 0.023 & 0.16 & 0.023 & 0.15 \\
\hline Family size & 4.22 & 1.30 & 2 & 12 & 4.22 & 1.32 & 4.21 & 1.29 \\
\hline Age & 43 & 9.87 & 20 & 65 & 42.34 & 9.89 & 42.68 & 9.807 \\
\hline Spouse works & 0.219 & 0.414 & 0 & 1 & 0.17 & 0.38 & 0.23 & 0.42 \\
\hline Marginal income tax & 26.57 & 3.77 & 0 & 53.98 & 26.443 & 4.649 & 26.603 & 3.456 \\
\hline
\end{tabular}

Sample size: 8286 quarter-household observations on 3234 households

1. All monetary magnitudes in $1000 \mathrm{~s}$ of euro (constant prices of 1987). Household income is the sum of primary and secondary earner earnings

2. Sample selection: Households headed by a continuously married employee, between 20 and 65 years of age. We exclude observations in which consumption was more (less) than $7.38(0.13)$ times consumption four quarters before

3. Periodification of expenditure is done by applying the depreciation rates in Hulten and Wykoff (1995) to purchases of new durable goods when a purchase is observed. See text

4. The marginal income tax is computed on the first monetary unit of capital income and depends in principle on the filing status. To impute the household POST 88 filing status, we computed for each observation the amount paid using joint and separate filing and assigned that with the lower tax burden

\subsection{Empirical strategy}

The empirical analysis proceeds in three steps. The first verifies that pre-tax labor earnings and the age at the time of the introduction of the tax incentives of retirement saving are strong predictors of both the probability of contributing and of the amount contributed to pension plans. To that end, we use the 1988-1991 panel of tax returns. The second step builds on the previous results and examines the evolution of mean consumption growth of the groups that, according to the panel of tax returns, used the contributions most heavily. The data set used in this step is the expenditure survey. While this strategy allows us to detect falls in expenditure around the time of the introduction of the tax incentives, we cannot quantify how much new saving is created. Thus, in the third step we use TwoSample Two-Stage Least Squares to relate mean contributions to pension plans and mean drops in expenditure. In what follows, we discuss each of these steps in detail. 
Table 3 Summary statistics, expenditure survey (ECPF) — top half of distribution of earnings

\begin{tabular}{|c|c|c|c|c|c|c|c|c|}
\hline \multicolumn{5}{|c|}{ Households in top half of the distribution of earnings } & \multicolumn{2}{|c|}{$1985.1-1987.1$} & \multicolumn{2}{|c|}{$1987.2-1990.4$} \\
\hline & Mean & SD & Min. & Max. & Mean & SD & Mean & SD \\
\hline Quarterly total expenditure & 2.597 & 1.850 & 0.120 & 35.246 & 2.332 & 1.433 & 2.685 & 1.960 \\
\hline $\begin{array}{l}\text { Quarterly expenditure } \\
\text { (periodified) }\end{array}$ & 2.526 & 1.517 & 0.119 & 14.344 & 2.266 & 1.292 & 2.611 & 1.575 \\
\hline $\begin{array}{l}\text { 4-Quarter change in log } \\
\text { expenditure }\end{array}$ & 0.0218 & 0.55 & -1.99 & 1.953 & 0.009 & 0.544 & 0.0260 & 0.553 \\
\hline $\begin{array}{l}\text { 4-Quarter change log } \\
\text { expenditure (periodified) }\end{array}$ & 0.08 & 0.50 & -1.99 & 1.91 & 0.06 & 0.50 & 0.086 & 0.50 \\
\hline $\begin{array}{l}\text { Household (yearly) pre-tax } \\
\text { earnings }\end{array}$ & 13.280 & 5.747 & 6602 & 81.980 & 10.917 & 4.675 & 14.057 & 5.854 \\
\hline $\begin{array}{l}\text { 4-Quarter change in pre-tax } \\
\text { earnings }\end{array}$ & 0.023 & 0.156 & -1.463 & 0.973 & 0.023 & 0.16 & 0.023 & 0.15 \\
\hline Family size & 4.25 & 1.25 & 2 & 11 & 4.215 & 1.324 & 4.254 & 1.23 \\
\hline Age & 43 & 9.12 & 20 & 65 & 42.16 & 9.26 & 42.55 & 9.07 \\
\hline Spouse works & 0.321 & 0.467 & 0 & 1 & 0.257 & 0.437 & 0.342 & 0.474 \\
\hline Marginal income tax & 28.75 & 3.74 & 23.74 & 53.98 & 28.186 & 4.694 & 28.919 & 3.426 \\
\hline Sample size & & 4246 & & & 1051 & & 3195 & \\
\hline
\end{tabular}

Sample size: 4246 observations on 1740 households observed in the top half of the earnings distribution in the quarter of the interview see notes to Table 5

\subsubsection{Distribution of contributions when tax incentives were introduced}

Following the theoretical considerations sketched in Sect. 3, we examine both contributions to pension plans around the date of the introduction of tax incentives of retirement savings. As already mentioned, we expect households with higher-income marginal tax rates to experience a larger increase in return to new retirement saving and, thus, to have a higher incentive to contribute. Second, within households with similar income marginal tax rates, those in the latter part of their working lives should be the most likely to contribute, as wealth is plausibly higher, and income risk and liquidity considerations are less relevant. We check these hypotheses using the panel of tax returns to compute the average probability of contributing and the average contribution by age group (holding the quartile of labor earnings constant). We divide the sample along two dimensions: (i) age groups (in four 10-year brackets), and (ii) the quartile pre-tax labor earnings of the 1987 tax filing unit. This easily identifies individuals who contributed to pension plans by most after the introduction of tax incentives of retirement savings.

\subsubsection{Changes in expenditure when tax incentives were introduced}

In the second step we compare the consumption growth for households with highincome marginal tax rates in the later part of their working lives (the group with the highest incentive to contribute) to that of individuals with high-income marginal tax rates but headed by a person below 35 years of age (a group with lower incentives, given 
the illiquidity of the investment). Note that everyone who files a tax return qualifies for the subsidy, so a group of ineligibles does not really exist. Instead, our definition of "treatment" and "control" is defined by the differential incentive to contribute faced by households in different income quartiles. ${ }^{13}$ That test based on consumption growth has the advantage of controlling for unobserved differences between the "control" and "treatment" group, as long as they remain constant over time. It is also unaffected by trends in saving that affected similarly to individuals within the same income quartile or within the same age group. ${ }^{14}$

We estimate the following equation separately for the top two quartiles of the pretax family earnings (where the earnings quartile is determined by the first time we observe the household in the sample):

$$
\begin{aligned}
\log C_{h, q+4}-\log C_{h, q}= & \beta_{0}+\sum_{i=1}^{i=3} \beta_{i}\left(\text { Age } \_i\right)_{h} \text { POST } 88_{q}+\beta_{4} \text { POST } 88_{q} \\
& +\sum_{i=1}^{i=3}\left(\text { Age } \_i\right)_{h} \beta_{4+i}+\beta_{8} X_{\mathrm{it}}+\varepsilon_{h, q+4}-\varepsilon_{h, q}
\end{aligned}
$$

The dependent variable is the household-specific difference between total expenditure four quarters ahead and current total expenditure. Age $i$ are three dummies indicating whether or not the household head is between 36 and 45 years old, 46 and 55 years old, or 56 and 65 years old. POST $88_{q}$ is a dummy indicating whether or not quarter $q$ is before or after 1987.1 (that is, if the four periods ahead observation on expenditure happens after the introduction of the program). $X_{\text {it }}$ contains year and quarter dummies (excluding the fourth quarter) that capture aggregate changes associated with the business cycle, the level and four-quarter change of household size (number of members) and composition (the number of and four-quarter change of the number of household members between 1 and 2 years of age, 3 and 5, 6 and 13, 14 and 17 and with more than 65 years of age). It also contains the level of gross household earnings and the four-quarter change in household earnings. To control for the change in reporting mode in 1988 that may have increased the expected lifetime income of couples by allowing separate filing, we include two extra dummies: (i) an intercept of "both members of the couple work," and (ii) "both members work" interacted with the POST 88 dummy. Those variables capture any mechanical effect of separate filing

\footnotetext{
13 In some sense, the literature on the elasticity of taxable income to marginal income taxes faces the same problem, as no tax filer is really excluded from a change in marginal taxes (see Gruber and Saez 2002 or, in the case of Spain, Almunia and Rodríguez-López 2019). We borrow from that literature in defining treatment and control groups on the basis of differences in marginal income taxes based on last year's income.

14 One could argue that the right comparison is between the consumption growth of individuals who actually contribute and those who do not. Nevertheless, in using the incentive to contribute rather than actual contributions as the key covariate we follow most of the literature on 401(k)s. Even with complete samples, Engen and Gale (2000), Poterba et al. (1996) and others assess the impact of 401(k)s by comparing trends in saving behavior between households eligible and non-eligible for 401(k) and disregard the comparison between contributors and non-contributors. To reinforce our argument, notice that variations in actual contributions are correlated with unobserved variables that may have a separate impact on consumption growth beyond interest rate increases (time preference or changes in the preferences for liquidity).
} 
on expected lifetime income. As for behavioral responses, we briefly discuss them in Sect. 6.3. We do not include changes in other sources of income (like interest rates), because saving in interest-yielding assets is likely to change due to the introduction of the exemption.

The coefficients $\beta_{1}, \beta_{2}$ and $\beta_{3}$ give the averages of individual changes in expenditure growth in a specific demographic group relative to the "base" group of individuals below 35 years of age. Those averages mix households that contribute to pension plans and those that do not. Note that only contributors faced an increase in the return to new retirement saving at the time of the introduction of the program. If contributions were financed from changes in consumption we would expect $\beta_{1}, \beta_{2}$ and $\beta_{3}$ to be negative. On the contrary, if contributions were financed from reshuffling assets, and not from higher saving, we would expect $\beta_{1}, \beta_{2}$ and $\beta_{3}$ to be nonnegative. ${ }^{15}$

Mean impacts on consumption changes may not be the only relevant moment. The proportion of filers who contributed to pension plans between 1988 and 1991 was low (see Table 1). Thus, the introduction of tax incentives is unlikely to have generated a constant impact throughout the distribution of consumption changes; on the contrary, it is likely to be located in specific centiles of the distribution. Second, our expenditure measure includes durable goods. If households delayed the purchase of a car or of new furniture to finance their contributions, we would expect again a nonlinear impact over the distribution of expenditure changes. Thus, as a further specification check, we report quantile regression estimates of the impact of the interaction of age dummies and income group on the 25th, 50th, and 75th centiles of the distribution of consumption changes. Finally, and given that consumption growth is clearly heteroscedastic, we tighten our estimates presenting Weighted Least Squares (WLS) estimates, weighting observations by the inverse of the absolute value of the residual of a consumption change equation estimated by OLS. ${ }^{16}$

\subsection{Robustness checks}

A potential problem with model (1) is that it attributes any differential trend in expenditure growth that happened between 1985 and 1990 in the age groups we consider to the introduction of tax incentives of retirement saving. To control for age-specific trends, in some specifications we use as a benchmark the evolution of consumption of the group with incomes between the 50th and the 75th centile of the distribution of earnings (a group with high pre-tax income but a lower incentive to contribute). Namely, using the subsample of households whose income is above the median, we estimate the following model:

\footnotetext{
15 We compute standard errors allowing arbitrary heteroscedasticity and autocorrelation within observations from the same household. Bertrand et al. (2004) argue that if there is positively autocorrelation in the dependent variable, standard errors in DD applications may be artificially low. However, note that in our case, the dependent variable, changes in log consumption is negatively autocorrelated (coefficient of group-specific autocorrelation: -0.16), in which case the standard errors we report are not affected by Bertrand et al's concerns necessarily.

16 WLS does not always lead to unbiased estimators due to the difficulties in modeling variances. To assess whether or not this is a problem, Table 5 reports both OLS and WLS estimates below, to permit informal comparisons of the differences in point estimates.
} 


$$
\begin{aligned}
\log C_{h, q+4}-\log C_{h, q}= & \left.\beta_{0}+\sum_{i=1}^{i=3} \gamma_{i} \text { Age } \_i\right)_{h} \operatorname{POST} 88_{q} * 1\left(Y>Y_{0.75}\right) \\
& \left.+\sum_{i=1}^{i=3} \gamma_{4+i} \text { Age } \_i\right)_{h} \operatorname{POST} 88_{q}+\gamma_{8} \operatorname{POST} 88_{q} * 1\left(Y>Y_{0.75}\right) \\
& \left.\left.+\sum_{i=1}^{i=3} \gamma_{8+i} \text { Age } \_i\right)_{h} * 1\left(Y>Y_{0.75}\right)+\sum_{i=1}^{i=3} \gamma_{12+i} \text { Age } \_i\right)_{h} \\
& +\gamma_{16} \operatorname{POST} 88_{q}+\gamma_{17} 1\left(Y>Y_{0.75}\right)+\gamma_{18} X_{\mathrm{it}}+u_{h, q+4}-u_{h, q}
\end{aligned}
$$

Model (2) attributes to tax incentives any trend in the expenditure growth of households in the later part of their working life and in the upper quartile of the distribution of earnings that is different from the corresponding trend in the second quartile of the distribution of earnings. Model (2) makes the implicit assumption that, if tax incentives of retirement saving had not been introduced, the difference in consumption growth between households in the top quartile with ages above 45 and households below 35 would have evolved as the same difference among households in the second-to-top income quartile. We test the assumption below.

\subsubsection{The impact of contributions to pension plans on new household saving}

A parameter commonly used in the literature that evaluates the impact of tax incentives on retirement saving is "How much new saving does an extra euro of contributions generate"? In our setting, a way of obtaining such measure is expressing the average consumption drop among groups who relatively contributed more to pension plans as a fraction of the amount that those same groups contributed to pension plans in excess of other groups. Namely, we are interested in the parameter $\alpha_{1}$ :

$\alpha_{1}=\frac{E\left[C_{\mathrm{it}}^{\mathrm{POST} 88}-C_{\mathrm{it}}^{\mathrm{PRE} 88} \mid \text { Age } \_i \geq 36, Y_{\mathrm{it}}\right]-E\left[C_{\mathrm{it}}^{\mathrm{POST} 88}-C_{\mathrm{it}}^{\mathrm{PRE} 88} \mid \text { Age } \_i<36, Y_{\mathrm{it}}\right]}{E\left[\text { Contr }{ }_{\mathrm{it}}^{\mathrm{POST} 88} \mid \text { Age } \_i \geq 36, Y_{\mathrm{it}}\right]-E\left[\text { Contr }{ }_{\mathrm{it}}^{\mathrm{POST} 88} \mid \text { Age } \_i<36, Y_{\mathrm{it}}\right]}$

where $C_{\text {it }}$ measures yearly consumption after and before the introduction of tax incentives and Contr $r_{i t}$ is the amount contributed to pension plans in the early years when the exemption was introduced. The numerator of the expression is the average consumption drop of households above 36 years of age, relative to that of households below 36 years of age. The denominator is the average amount contributed by households headed by an individual above 36 years of age relative to that contributed by households below 36 years.

The parameter $\alpha_{1}$ can be estimated using a Two-Sample Least Squares estimator of the impact of the amount contributed on the consumption of the household, where contributions are instrumented (see Angrist and Krueger 1992). The key instrument in our study is an age trend that differs with respect to the 20-35 age group that operates after 1988 within the top income quartile but not within the second-to-top 
income quartile. Thus, we assume that such differential trend only affects consumption growth through its impact on contributions to pension plans and then is correlated with contributions but not with consumption changes.

We implement the TSLS estimator as follows. In the panel of tax returns, we use the 1988-1991 waves to estimate:

$$
\text { Contr }_{\text {it }}=\delta_{0}+\sum_{i=1}^{i=3} \delta_{i} \text { Age } \_i * 1\left(Y>Y_{0.75}\right)+\delta_{4} 1\left(Y>Y_{0.75}\right)+\sum_{i=1}^{i=3} \delta_{i} \text { Age } \_i+u_{i}
$$

In the consumption survey, we estimate

$$
\begin{aligned}
& \Delta C_{\mathrm{it}}=\alpha_{0}+\alpha_{1} \widehat{\operatorname{Contr}_{\mathrm{it}}}+\alpha_{2} \text { POST } 88_{t} * 1\left(Y>Y_{0.75}\right)+\sum_{i=3}^{i=5} \alpha_{i} \text { Age } \_i * \text { POST } 88 \\
& +\sum_{i=6}^{i=8} \alpha_{i} \text { Age } \__{i} i * 1\left(Y>Y_{0.75}\right)+\alpha_{9} \text { POST } 88_{t}+\alpha_{10} 1\left(Y>Y_{0.75}\right)+\sum_{i=11}^{i=14} \alpha_{i} \text { Age } \_i+\varepsilon_{\text {it }}
\end{aligned}
$$

where $\widehat{\text { Contr }_{i t}}$ is the OLS prediction in the sample of tax returns.

Two notes of caution about the TSLS exercise. The first is that both samples differ in their sampling and population coverage: the panel of tax returns captures the rich in a much better way than the panel of expenditure. While we think this is less of a problem for the exercise that merely detects consumption drops, as that specification only requires identifying broad groups that contribute, it may be somewhat problematic for imputing contributions within cells. The second note of caution is that the specifications with the level of consumption as a dependent variable are somewhat noisy, leading to imprecise estimates. For those two reasons, we emphasize less the new saving results than the rest of the results.

\section{By how much did tax incentives promote contributions to pension plans?}

Table 4 presents the size of contributions to pension plans of different population groups obtained using the 1988-1991 waves of the Panel of Tax Returns. Population groups are defined by age groups (in four 10-year brackets) and the pre-tax labor earnings of the 1987 tax filing unit. The centiles are computed using the Expenditure Survey, to keep consistency across samples.

Panel A shows the distribution of contributions in the top quartile of the labor earnings distribution. The unconditional mean contribution increases with age; the unconditional mean contribution (Table 4, row 1, column 1) in the lowest age group is 62.72 euros; the same mean contribution in the group close to retirement (Table 4, row 1, column 4) is four times higher, 269.2 euros. The percentage of filing units with at least one contributor was relatively small and also varies monotonically with age, from $6 \%$ in the group of filers with ages between 20 and 35 years of age to $12 \%$ in 
Table 4 Contribution to pension funds by age and income group, 1988-1991. Source: 1988-1991 Panel of Income Tax Returns, sample of households where main filer is an employee. All magnitudes in 1000 euros

\begin{tabular}{llll} 
(1) & $(2)$ & $(3)$ & $(4)$ \\
Age 20-35 & Age 36-45 & Age 46-55 & Age 56-65 \\
\hline
\end{tabular}

Panel A: Gross annual labor earnings in the top quantile of the ECPF

$\begin{array}{lllll}\text { 1. Amount contributed (includes 0s) } & 0.063 & 0.125 & 0.181 & 0.269 \\ \text { 2. Percentage households that contribute } & 0.061 & 0.092 & 0.115 & 0.121 \\ \text { 3. Contribution/taxable income (if positive) } & 0.068 & 0.0647 & 0.071 & 0.106 \\ \text { 4. Exhausts limit? } & 0.122 & 0.122 & 0.142 & 0.305 \\ \quad \text { Sample size } & {[48,027]} & {[40,325]} & {[22,241]} & {[11,938]} \\ \text { Marginal income tax } & 33.4 & & & \end{array}$

Panel B: Gross annual labor earnings in the second quartile in the ECPF

$\begin{array}{lllll}\text { 5. Amount contributed } & 0.018 & 0.029 & 0.041 & 0.059 \\ \text { 6. Percent contribution } & 0.0314 & 0.041 & 0.047 & 0.047 \\ \text { 7. Contribution/income (if positive) } & 0.054 & 0.0971 & 0.079 & 0.115 \\ \text { 8. Exhausts limit? } & 0.084 & 0.105 & 0.136 & 0.268 \\ \quad \text { Sample size } & {[34,540]} & {[17,291]} & {[12,190]} & {[9471]} \\ \quad \text { Marginal income tax } & 26.56 & & & \end{array}$

Panel C: Gross annual labor earnings in the bottom half of the ECPF

$\begin{array}{lllll}\text { 9. Amount contributed } & 0.007 & 0.029 & 0.020 & 0.025 \\ \text { 10. Percent contribution } & 0.014 & 0.0246 & 0.027 & 0.022 \\ \text { 11. Contribution/income (if positive) } & 0.076 & 0.0971 & 0.198 & 0.134 \\ \text { 12. Exhausts limit? } & 0.12 & 0.105 & 0.197 & 0.317 \\ \quad \text { Sample size } & {[86,799]} & {[26,861]} & {[18,313]} & {[19,362]}\end{array}$

1. Each tax filing unit in 1987 (a period of compulsory joint tax filing by couples) contributes an observation per year, regardless of filing mode

2. Sample partitions were done according to the pre-tax family earnings centiles in the ECPF

3. Labor earnings are the sum of gross earnings (including tax withholdings and social security contributions) declared by the filing unit if the original tax unit in 1988 continues to file jointly and of the tax reports of the spouses in the case of separate filings

the group between 56 and 65 years of age (Table 4, Panel A, row 2, columns 1 and 4, respectively).

The proportion of filers exhausting the limits is roughly constant up to 56 years of age (12\% of tax filers who contributed to pension plans in the previous years, row 4 Panel A of Table 4). In the latter part of the working life, the fraction is much higher, 30\% (Table 4, row 4, column 4). That finding is consistent with our prior that a substantial fraction of the contributions to pension plans of filers in the later part of their working life may arise from reshuffling wealth portfolios.

Panels B and C in Table 4 present similar summary statistics for the second quartile of the labor income distribution (Panel B) and the bottom two quartiles (Panel C). The unconditional group-specific average population fraction that contributed to a pension plan is between 3 and 6 times smaller than in the top earnings quartile. Still, for all 
income groups, the fraction of contributors in the verge of retirement that exhaust the tax exemption limit is about $30 \%$.

Overall, the evidence in Table 4 suggests that, if there is an impact of contributions on household expenditure, it can mostly be found in the top quartile of the (pre-tax) earnings distribution. In addition, the impact should vary with age. Of course, some households in the bottom three quartiles of the income distribution may have made substantial contributions to pension plans. Nevertheless, as a group, we can only expect a little impact of the introduction of pension plans on the expenditure of the bottom three quartiles of the income distribution. This leads us to make some use of households in the second-to-top income quartile as an additional control group.

\section{Did tax incentives to retirement savings raise households' saving rates?}

This section presents the estimates of the fall in expenditures around the introduction of tax incentives of retirement savings. Table 11 in the Appendix presents our empirical strategy in diff-in-diff form. Each entry in Table 11 in the Appendix shows the average of household-specific expenditure growth, by income and age group. Row 1, column 1 of Table 11 in the Appendix shows that prior to the exemption, average consumption growth in the top income quartile for the 46-65 age group was $6.8 \%$, while in the group of 20-35 years of age consumption growth was $1.1 \%$ (row 2, column 1 of Table 11 in the Appendix). After the introduction of the exemption, expenditure growth in the group of 46-65 years of age fell to $1 \%$, while it was $8.3 \%$ in the group of $20-35$ years of age. That results in a diff-in-diff estimate of -0.13 (a fall of $13 \%$ ). Row 4 in the second panel shows the change in consumption growth for the age 46-65 age group in the second-to-top income quartile. That group experimented an increase in expenditure growth of $2 \%$ (see row 4, column 3 ). In the second-to-top income quartile, households in the 20-35 age group experimented an average expenditure growth of $5.5 \%$. The corresponding diff-in-diff estimate is $-3.5 \%$, much lower than the -0.13 estimate in row 3, column 3.

We provide further illustration of the dynamics of the effect in Figs. 1 and 2. To detect whether there was an age-related discontinuity in consumption growth that started in 1987, we ran year-specific OLS regressions of household expenditure growth on a dummy indicating whether the age of the head was between 36 and 65 years of age. ${ }^{17}$ Each estimate in each year measures the difference in log expenditure growth between households in the later part of the life cycle and our control group of young households. Figure 1 shows the estimates of the yearly age dummies for households in the top income quartile. Before the exemption (in years 1985 and 1986), log expenditure changes of groups above 36 years of age was between 5 and $10 \mathrm{pp}$ higher than that the 20-35 age group. However, expenditure growth of groups above 36 years became 5 pp lower than that of individuals 35 or below in 1988 and stayed around zero during the rest of the sample period. The corresponding estimates for households in the

\footnotetext{
17 The omitted group are households headed by a person between 20 and 35 years of age. To hold household composition constant, we also add as covariates one-year changes in demographics (changes in the number of children, elderly and overall number of household members).
} 


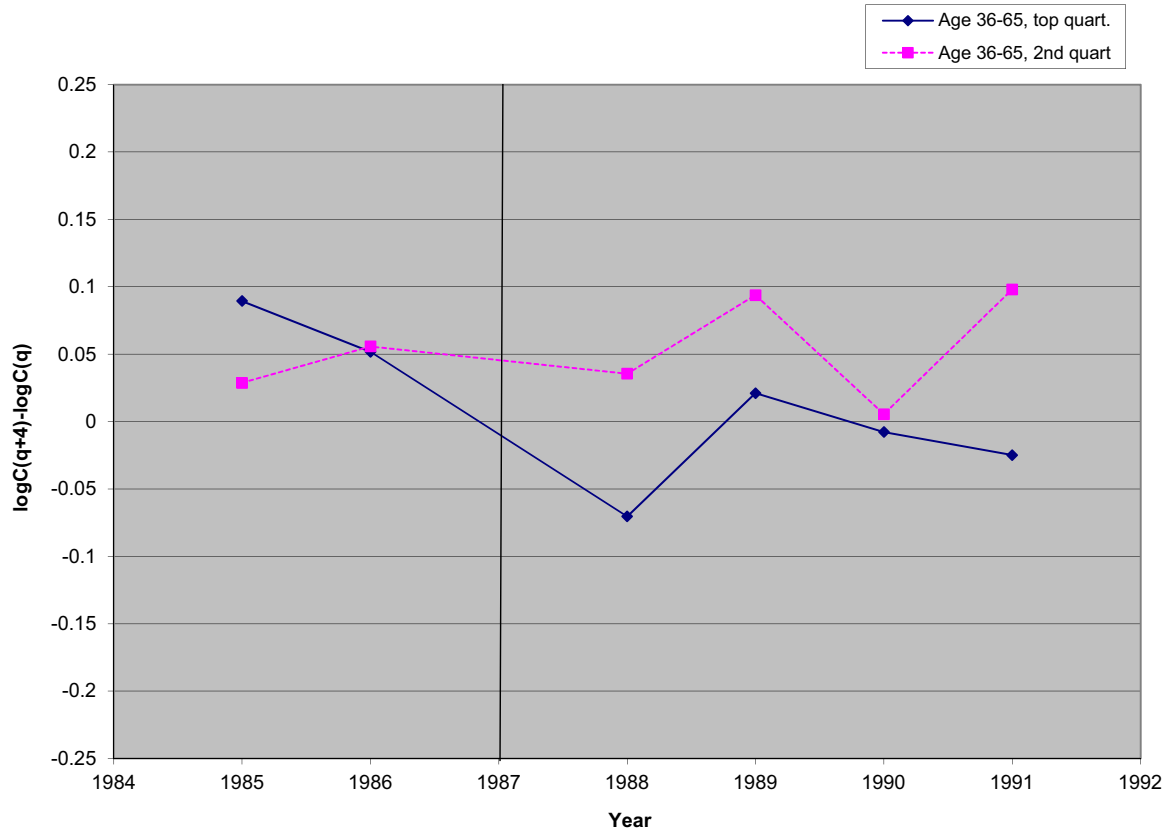

Fig. 1 Expenditure growth relative to 20-35, 1985-1991

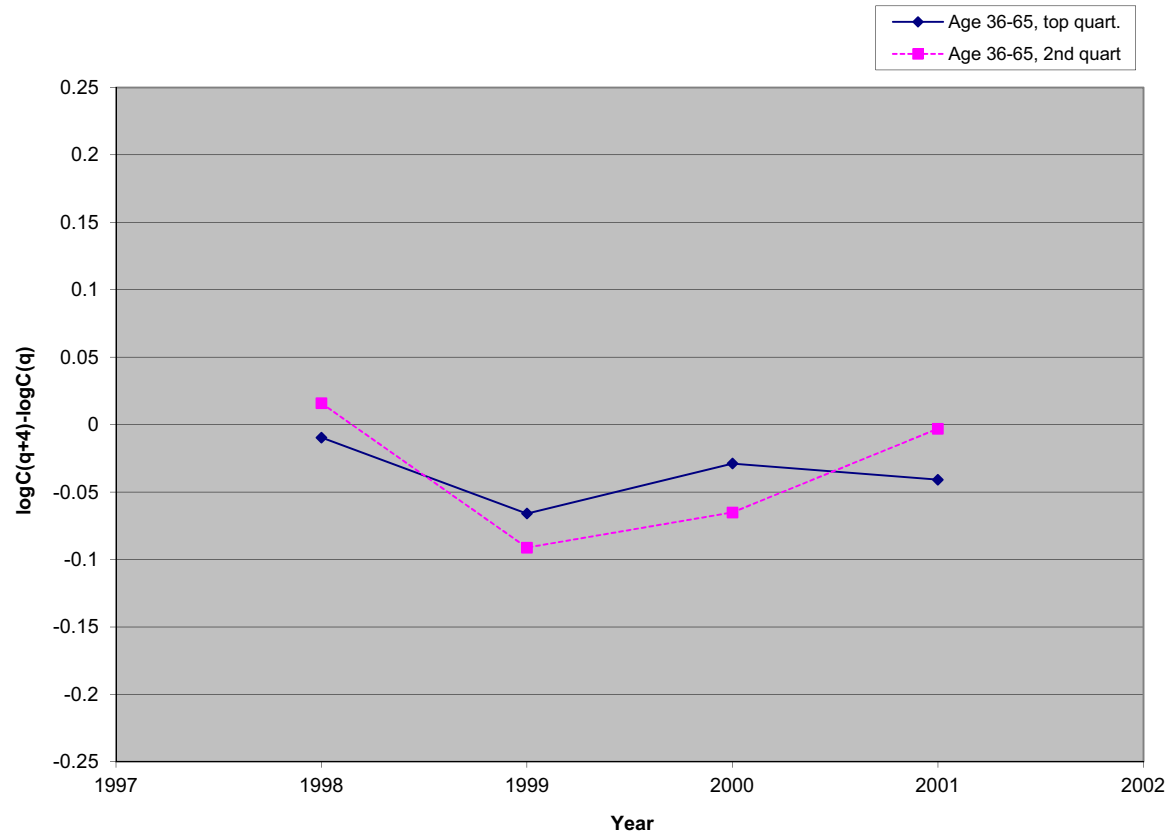

Fig. 2 Expenditure growth relative to 20-35, 1998-2001 
second-to-top income quartile (who contributed much less to pension plans) show that, unlike households in the top income quartile, one-year ahead expenditure growth of the group above 36 was higher than that of households 35 or below either before and after 1988.

We interpret that the lower growth of expenditure among individuals above 36 years of age is the result of households who start contributing to pension plans and adjust their previous consumption path to a new one with higher post-tax interest rates. However, other interpretations are possible. For example, differential age-income trends in an expansion like that between 1988 and 1991 could explain the result. We test for that possibility redoing the analysis during the period 1998-2001 in Fig. 2. By 1998, the fraction of new filers had stabilized at $24 \%$, so few households would be changing their consumption paths. In that case, there would be no reason to expect lower consumption growth among prime age households at the top of the income distribution. Figure 2 shows that, relative to very young households below 35 years of age, expenditure growth among prime age households was very similar at the top of the income distribution and at the second-to-top income quartiles. In sum, the lower growth of expenditure is only observed among mature households with high marginal income taxes only at the time of the introduction of tax incentives to retirement saving.

\subsection{Regression evidence (D-in-D)}

We start by examining the evolution of household expenditure among households in the top quartile of the income distribution using estimates from equation (1). Consumption growth of individuals between 56 and 65 years of age (relative to households between 20 and 35 years of age) is estimated to have fallen by $9.8 \%$ after the introduction of the program (row 1, column 1 of Table 5). However, this estimate is very imprecise and not significantly different from zero (the standard error is $12.3 \%$ ). The corresponding drop in consumption expenditure growth for the group between 46 and 55 years of age is $21.7 \%$, significantly different from zero at the $5 \%$ confidence level $(-0.217$, shown in row 2, column 1, Table 5). Finally, for the group between 36 and 45 years of age the drop in relative consumption expenditure growth is $8.7 \%$, which is consistent with the notion that households cut their expenses upon the introduction of the program. Nevertheless, the estimate is imprecise.

Column 2 presents Weighted Least Squares (WLS) estimates of magnitude similar to the OLS case, but much more precise standard errors. The impact is again negative for all age groups and significantly different from zero at conventional confidence levels. The impact is not monotonic with age, and the highest impact is located among the group with 46-55 years of age.

\subsubsection{Heterogeneity of the response: quantile regressions}

As mentioned above, the fact that few households had exempted contributions in the early years following 1988 coupled with the presence of durable goods in our measure of expenditure lead us to expect that the age-specific drop in consumption growth was not uniform. Columns 3 through 6 of Table 5 confirm that hypothesis for the 
Table 5 Changes in expenditure among groups above median income, by age group

\begin{tabular}{|c|c|c|c|c|c|}
\hline \multirow[t]{3}{*}{ Estimation method } & \multicolumn{5}{|c|}{ Period: $85: 1-90: 4$} \\
\hline & OLS & WLS & Quan & ssion & \\
\hline & (1) & (2) & $\begin{array}{l}25 \text { th } \\
(3)\end{array}$ & $\begin{array}{l}\text { Median } \\
\text { (4) }\end{array}$ & $\begin{array}{l}75 \text { th } \\
(5)\end{array}$ \\
\hline
\end{tabular}

Dependent variable: 4-quarter changes in the logarithm of expenditure

"Treated" group: household income above 75th centile

$\begin{array}{llllll}\text { 1. Age 56-65* (POST 88) } & -0.098 & -0.111 & -0.17 & -0.171 & -0.182 \\ & (0.123) & (0.025)^{* *} & (0.128) & (0.156) & (0.202) \\ \text { 2. Age 46-55* (POST 88) } & -0.217 & -0.214 & -0.109 & -0.194 & -0.349 \\ & (0.086)^{* *} & (0.016)^{* *} & (0.129) & (0.112)^{*} & (0.134)^{* *} \\ \text { 3. Age 36-45* (POST 88) } & -0.087 & -0.096 & -0.057 & -0.113 & -0.110 \\ & (0.075) & (0.011)^{* *} & (0.094) & (0.075) & (0.12)\end{array}$

Sample size

2051

"Control" group: household income between 50th and 75th centile

$\begin{array}{cccccc}\text { 4. Age 56-65* (POST 88) } & -0.022 & -0.013 & 0.008 & -0.055 & 0.065 \\ & (0.104) & (0.035) & (0.125) & (0.145) & (0.12) \\ \text { 5. Age 46-55* (POST 88) } & -0.033 & -0.027 & -0.109 & -0.006 & 0.062 \\ & (0.078) & (0.017) & (0.094) & (0.088) & (0.097) \\ \text { 6. Age 36-45* (POST 88) } & -0.028 & -0.028 & -0.105 & -0.017 & 0.058 \\ & (0.077) & (0.014)^{* *} & (0.094) & (0.085) & (0.098)\end{array}$

Sample size

2195

Dependent variable: 4-quarter change in the level of expenditure

"Treated" group: household earnings in top quartile

$\begin{array}{cccccc}\text { 7. Age 56-65* (POST 88) } & -0.012 & -0.122 & -0.528 & -0.680 & -0.427 \\ & (0.510) & (0.090) & (0.312) & (0.372) & (0.558) \\ \text { 8. Age 46-55* (POST 88) } & -0.687 & -0.697 & -0.290 & -0.508 & -0.656 \\ & (0.417)^{*} & (0.053)^{* *} & (0.284) & (0.263)^{*} & (0.38) \\ \text { 9. Age 36-45* (POST 88) } & -0.058 & -0.179 & -0.182 & -0.286 & -0.064 \\ & (0.310) & (0.046)^{*} & (0.247) & (0.193) & (0.274)\end{array}$

Dependent variable: 4-quarter change in bulky purchases (cars, white and electronic goods, furniture)

\begin{tabular}{|c|c|c|c|c|c|}
\hline \multirow[t]{2}{*}{ 10. Age $56-65^{*}($ POST 88$)$} & 0.164 & 0.750 & -0.082 & - & -0.077 \\
\hline & $(0.408)$ & $(0.150)^{* *}$ & $(0.115)$ & & $(0.083)$ \\
\hline \multirow[t]{2}{*}{ 11. Age $46-55^{*}($ POST 88$)$} & -0.475 & -0.324 & -0.034 & - & -0.222 \\
\hline & $(0.330)$ & $(0.021)^{* *}$ & $(0.054)$ & & $(0.118)^{*}$ \\
\hline
\end{tabular}


Table 5 continued

\begin{tabular}{|c|c|c|c|c|c|}
\hline \multirow[t]{3}{*}{ Estimation method } & \multicolumn{5}{|c|}{ Period: $85: 1-90: 4$} \\
\hline & \multirow{2}{*}{$\begin{array}{l}\text { OLS } \\
\text { (1) }\end{array}$} & \multirow{2}{*}{$\begin{array}{l}\text { WLS } \\
\text { (2) }\end{array}$} & \multicolumn{3}{|c|}{ Quantile regression } \\
\hline & & & $\begin{array}{l}25 \text { th } \\
(3)\end{array}$ & $\begin{array}{l}\text { Median } \\
\text { (4) }\end{array}$ & $\begin{array}{l}75 \text { th } \\
(5)\end{array}$ \\
\hline 12. Age $36-45^{*}($ POST 88$)$ & $\begin{array}{l}0.032 \\
(0.227)\end{array}$ & $\begin{array}{l}0.026 \\
(0.014)^{*}\end{array}$ & $\begin{array}{l}0.035 \\
(0.057)\end{array}$ & - & $\begin{array}{l}-0.028 \\
(0.057)\end{array}$ \\
\hline
\end{tabular}

$+, *, * *$ means that the estimate is different from zero at the $15,10,5 \%$ confidence level

1. Dependent variable: $\log [$ expenditure quarter $(q+4)]-\log$ [expenditure $q$ ]. We drop cases in which total expenditure in $\mathrm{q}+4$ was larger (smaller) than $7.38(0.13)$ times expenditure in $q$

2. POST 88 is a dummy that takes value 1 if the period covered by the expenditure change includes a quarter after the first quarter of 1988. Omitted age group: 20-35 years of age

3. All models include the following covariates (not shown to save space): a POST 88 dummy, dummies for age 56-65, age 46-55, age 36-45, year and quarter dummies, period $q$ family earnings, the change in earnings between $q$ and $q+4$, the number and 4-quarter change of household members between 1 and 2 , 3 and 5, 6 and 13, 14 and 17 and above 65 and the 4-quarter change a dummy for "both members of the couple work and an interactions of "both work" and POST 88

4. Analytical standard errors corrected for heteroscedasticity and correlation within observations of the same household shown in columns 1 and 2. In columns 3-5, standard errors are bootstrapped 200 times, and each of the bootstrap replication samples is clustered at the household level

group of individuals between 46 and 55 years of age. The estimates shown in row 2, columns 3-5 of Table 5 suggest that the drops in consumption growth were driven by a few large changes: the 75th centile of the consumption drop was 35 log points (standard error: 0.13). ${ }^{18}$ Conversely median consumption growth did not change as much (19.4 log points, but the standard error is 11.2). In other words, the average drop in expenditure is due to the behavior of a limited set of households. For households close to retirement (56-65), we find a constant drop at different centiles, a finding that leads us to suspect that the estimates in row 1, column 1 of Table 5 may reflect other trends. Finally, for our youngest treatment group (individuals between 36-45 years of age), while the estimates are not significantly different from zero, the magnitude of the coefficients also suggests that the fall in consumption expenditure growth is also uniform over the distribution.

\subsubsection{Age differences in a "placebo" group: the second-to-top earnings quartile}

Rows 4 through 6 of Table 5 present estimates from a similar specification to that in Panel A, but for households with incomes between the 50th and the 75th centiles. Those households faced lower marginal tax rates on income and contributed less on average, as documented in Table 4 . Thus, if the decreases in consumption expenditure growth documented in rows 1-3 of Table 5 were indeed due to the introduction of tax incentives of retirement savings, we should find a lower impact of the introduction of the program on their consumption growth. The point estimates in row 5 (the group between 46 and 55 years of age) confirms that prior: the drop in consumption growth

18 Standard errors in the quantile regression specification were computed by 200 bootstrap replications in which the replications preserved the multiple observations of the same household in each of the replication samples. 
oscillates between 0.033 (OLS specification) and 0.027 (WLS specification), and they are significantly lower than in the top quartile of the distribution of earnings. Further, the distribution of the drop in expenditure among the 46-55 age group is very different from that in the top income quartile: the fall in consumption growth is not located at the largest centiles of the distribution of consumption growth.

\subsubsection{Results in levels and durable expenses}

Rows 7 through 9 in Table 5 repeat the analysis now using the change in the level (rather than logs) of consumption expenditures. The advantage of that specification is that one can readily interpret the magnitude of the consumption drop and informally compare it to the estimates in Table 4 and assess whether that the drop in consumption was indeed due to increases in contributions to pension plans. The results in row 8 of column 1 suggest that average expenditure among the group with ages between 46 and 55 fell by about 687 euros and that the average drop was far from constant, but driven by a relatively small set of households. Note that this average is much higher than the excess contribution of the 46-55 group with respect to the base group with ages between 20 and 35: (119 euros, as it results from subtracting column 1, row 1 from column 4, row 1 in Table 4).

In rows 10-12 of Table 5, we examine the concepts of expenditure that fall, and run a regression similar to equation (1), but in which the dependent variable only contains the following set of durable goods: "white" durable goods (purchases of fridges, dishwashers, washing machines, etc.), electronic goods (TVs, radios, CD players), cars and furniture. The results in row 11 suggest that, among the group that most diminished expenditure (46-55 years of age), the bulk of the adjustment happened due to a drop in expenses of durable goods. Results (not shown) also suggest that the drop in the expenditure growth of nondurable goods (food, textiles, transportation, health and entertainment) after 1988 was around 65 euros (standard error: 37.5 euros) among the group with ages between 46 and 55 years of age and a nonsignificant drop of 89 euros, (standard error: 428.6 euros) at the 90th centile of the distribution of consumption. The fact that the adjustment occurred through durables, coupled with the persistence of contributions (see Table 10 in the Appendix), gives a potential explanation of the discrepancy between the estimated consumption drop and the average annual contribution; households cut the stream of payments involved in the purchase of a durable good to sustain their contributions. ${ }^{19}$

\subsubsection{Summary}

Overall, from Table 5 we draw four main conclusions. First, the introduction in 1988 of tax incentives of retirement savings coincided with a drop in consumption expenditure growth among the treatment group of households between 45 and 56 years of age in the top income quartile, relative to our control group of households between 20 and

\footnotetext{
19 Gelber (2011) documents that after becoming eligible for 401(k) contributions, US households reduce the value of wealth held as cars, a result that also suggests that households finance contributions by deferring the purchase of durables. Our results are in line with that finding.
} 
35 years of age. We find less evidence of such an impact for households headed by individuals close to retirement age, a finding we discuss below. Second, the fall in both the log and in the level of household expenditures is driven by a few large changes, consistent with the notion that only a small fraction of households made contributions to pension plans. Thirdly, further evidence for the differential trend among the 46-55 age group between 1985 and 1991 being due to contributions to pension plans is the fact that the drop in expenditure was much lower within households in the same age group (46-55 years of age) within the second-to-the top income quartile (that, as a group, contributed much less to pension plans in the onset of the program). Fourthly, the evidence in the bottom part of Table 5 also suggests that households in the top quartile of the income distribution and who were between 46 and 55 years of age reacted to the introduction of the program by delaying bulky expenditures.

\subsection{Controlling for age-specific trends: triple differences}

Table 6 presents results from Model (2). Loosely speaking, that model uses an alternative strategy to "net out" age-specific trends by subtracting from the estimate of the drop in expenditure presented in Table 5, rows 1-3 column 2 (that among households in the top quartile of the income distribution, who were the largest contributors) the corresponding drop in expenditure reported in Table 5, rows 4-6 column (2)households in the second-to-top quartile, contributing much less. We report WLS, and estimates of the expenditure drop at different centiles. The estimates are similar to those reported in Table 5, rows 1-3, and we do not comment them in detail.

Panel B of Table 6 experiments with an additional source of identification. Our results so far use income quartiles to identify treatment and control groups. Yet, according to the theoretical discussion, tax incentives of retirement saving operate through the income marginal tax rate. The reason is that households with higherincome marginal tax rates experience a larger increase in the return to retirement saving and consequently a stronger substitution effect. Hence, we explore whether the expenditure drop after the introduction of tax incentives is stronger among households that faced higher-income marginal tax rates. ${ }^{20}$ We estimate the following model again for the top two quartiles of the distribution of earnings

$$
\begin{aligned}
& \left.\log C_{h, q+4}-\log C_{h, q}=\beta_{0}+\sum_{i=1}^{i=3} \delta_{i} \text { Age } \_i\right)_{h} \text { POST } 88_{q} \operatorname{mtax}_{h} \\
& \left.\left.+\sum_{i=1}^{i=3} \beta_{i} \text { Age } \_i\right)_{h} \operatorname{mtax}_{h}+\sum_{i=1}^{i=3} \beta_{3+i} \text { POST } 88_{q} \operatorname{mtax}_{h}+\sum_{i=1}^{i=3} \beta_{9+i} \text { Age } \_i\right)_{h} \\
& +\beta_{13} \text { POST } 88_{q}+\beta_{14} \operatorname{mtax}_{h}+\delta_{18} X_{\mathrm{it}}+v_{h, q+4}-v_{h, q}
\end{aligned}
$$

\footnotetext{
20 For each household in the sample, we computed the marginal income tax using the rules between 1985 and 1988, ignoring all capital income (that is, we compute the marginal income tax on the first euro of capital income). After 1988, for each household we estimated whether it was more tax-advantageous to file separately or jointly and, for those for whom separate filing was optimal, we imputed to the household the highest marginal income tax of the couple.
} 
Table 6 The impact of exemption on expenditure growth, accounting for age-specific trends

\begin{tabular}{lllll}
\hline Estimation method & WLS & \multicolumn{3}{l}{ Quantile regression } \\
\cline { 3 - 5 } & & 25th & Median & 75th \\
\hline Panel A: Households with earnings above the ECPF median, effect through dummies & \\
1. Age 56-65* (POST 88)* $(Y>y 0.75)$ & -0.039 & -0.101 & -0.072 & -0.141 \\
& $(0.042)$ & $(0.214)$ & $(0.215)$ & $(0.210)$ \\
2. Age 46-55* (POST 88)* $(Y>y 0.75)$ & -0.144 & 0.046 & -0.126 & -0.292 \\
3. Age 36-45* (POST 88)* $(Y>y 0.75)$ & -0.026 & 0.121 & 0.021 & -0.035 \\
& $(0.021)$ & $(0.131)$ & $(0.115)$ & $(0.127)$
\end{tabular}

List of regressors included in all specifications, but only shown for the WLS specification
4. Age $56-65 *($ POST 88$)$
$-0.036$
(0.034)
5. Age 46-55* (POST 88)
$-0.043$
$(0.017)^{*}$
6. Age 36-45* (POST 88)
$-0.052$
(0.017)
7. Age $56-65 *(Y>y 75)$
$-0.009$
(0.038)
8. Age $46-55^{*}(Y>y 75)$
0.062
9. Age $36-45^{*}(Y>y 75)$
(0.019)
$-0.004$
(0.019)
10. $1(Y>y 75) *$ POST 88
0.045
(0.017)
11. Age 56-65
0.075
(0.033)
12. Age 46-55
0.065
(0.015)
13. Age 36-45
0.053
(0.016)
14. $Y>y 75$
0.003
(0.015)
15. POST 88
0.059
(0.015)

Panel B: Households with earnings above the ECPF median, effect through the marginal tax on income
1. Age 56-65*(POST 88$) *$ MTAX
$-0.25$
$-0.16$
$-0.14$
$-0.37$
$(0.10)^{* *}$
(0.40)
(0.39)
(0.51)
2. Age $46-55 *(\operatorname{POST} 88) *$ MTAX
$-0.31$
$-0.35$
$-0.33$
$-0.81$
$(0.08)^{* *}$
(0.27)
(0.26)
$(0.39)^{* *}$
3. Age $36-45 *(\operatorname{POST} 88) *$ MTAX
$-0.18$
$-0.14$
$-0.23$
$-0.60$
$(0.06)^{* * *}$
(0.26)
(0.24)
(0.38) 
Table 6 continued

\begin{tabular}{lll}
\hline Estimation method & WLS & Quantile regression \\
\cline { 2 - 2 } & & \\
\hline 4. Age 56-65* MTAX & 0.08 & \\
& $(0.07)$ & \\
5. Age 46-55* MTAX & 0.40 & \\
& $(0.30)$ \\
6. Age 36-45* MTAX & 0.18 \\
& $(0.32)$ \\
7. MTAX* POST 88 & 0.01 \\
8. MTAX & $(0.24)$ \\
9. POST 88 & -0.73 \\
& $(0.28)$ \\
\end{tabular}

*,**means that the estimate is different from zero at the $10,5 \%$ confidence level, respectively. See notes Table 5

where Age $\_i$ stands for three age group dummies: 36-45, 46-55 and 56-65. The parameters of interest are $\delta_{1}, \delta_{2}$ and $\delta_{3}$ that measure the age-specific impact of income marginal tax rates on the average expenditure drop after the introduction of the exemption. If higher-income marginal tax rates are associated with larger drops in consumption growth for all age groups, we should expect $\delta_{1}, \delta_{2}$ and $\delta_{3}$ to be negative. The results shown in Table 6, Panel B, confirm that for the group between ages 46 and 55, higher consumption drops happened among households with higher-income marginal tax rates.

\subsection{Other changes correlated with the introduction of the exemption}

The exemption was introduced at the same time as a change in marginal income taxes and the introduction of tax splitting. To control for the change in marginal tax rates, we ran regressions very similar to (1) in the ECPF using marginal taxes as the dependent variable, finding very small effects. Possibly, the reason for this is that the new marginal taxes either affected households in the bottom of the income distribution (excluded from our subsample) or at the very top of the income distribution (who probably do not participate in an expenditure survey).

Furthermore, we examine whether our key variable that identifies the incentive to contribute (a differential trend between 1985 and 1990 among different age groups in the top quartile of the income distribution) is correlated with other outcomes, such as

1. Purchase of a house: Table 12 in the Appendix shows the evolution of the probability of purchasing a house in the ECPF before and after the 1988 reform, by age group. We find a sizable drop $(-1.7 \%$, relative to a overall mean of $2.3 \%$ ) in the probability of doing so in our base group, perhaps indicating that 
the drop in expenditure in the 46-55 age group was not confined to "small" durables.

2. Joint filing: The introduction of tax incentives of retirement savings in 1988 coincided with a major tax reform that changed compulsory joint filing to voluntary individual or joint filing. Such reform is likely to have changed the income marginal tax rate and the taxable income of households. In other words, the 1988 introduction of separate filing may have affected the expected permanent income and consumption of different age groups. For example, if joint filing was specially prevalent among households headed by our control group (persons between 20 and 36 years of age), the estimates in Model (1) would attribute to tax incentives what really is an income effect associated with a positive shock to labor supply. In principle, we focus on the top income quartile, that experienced similar tax changes, but there could be a problem if the option of separate tax filing varied across age groups. We check that possibility in Table 12 in the Appendix. Table 12 in the Appendix column 2 shows the impact of our instrument (a post 1988 dummy) on the probability that a tax filing unit files jointly. The group of tax filers headed by a person between 46 and 55 years of age was $3.7 \%$ more likely to file jointly than the base group. Thus, as a consequence of the tax reform, the 46-55 age group did not experience such an income increase as the base group. Still, it is not clear to what extent this is a problem. First, while the estimate is very precise, it is relatively small: less than $4 \%$ with respect to $64 \%$ of filers who filed jointly in that income group. Second, we control for changes in family income in our consumption regressions shown in Table 5, for an indicator of whether both members of the couple work and an interaction of that variable with the POST 88 dummy.

3. Spouse participation: We estimate a small drop of female participation in the group of households in the top income quartile headed by an individual between 46 and 65 years of age (1.6\% points), as shown in column 3 of Table 6 , but it is also very imprecisely estimated and not significantly different from zero. In addition, the modest drop in participation in the labor market is consistent with the small impact of our instrument on joint filing.

Overall, the finding that the choice of separate filing and female participation has such a modest age profile lead us to think that it is unlikely that the estimates presented in Tables 5 and 6 are driven by the introduction of separate filing.

\section{How much new saving are pension plans generating?}

This section combines expenditure data and data from contributions to estimate how much new saving was generated by the introduction of pension plans. The evidence in Table 5 suggest that the adjustment among the group with ages between 46 and 55 and in the top income quartile happened through drops in durable consumption expenditures (i.e., households delayed the purchase of a new car or furniture to contribute to pension plans). By definition, the periodicity of those expenses exceeds the year, 
so unadjusted comparisons of annual contributions to drops in observed expenditure with periodicity over the year are not informative. ${ }^{21}$

We use the depreciation rates in Fraumeni (1997) to distribute among several periods the bulky expenditure in durable goods when we observe one such purchase in the data. Namely, whenever we observe the purchase of a durable good, we attribute to the year of the purchase (and subsequent periods if the household stays in the sample) the fraction of the purchase that is depreciated. ${ }^{22}$ Unfortunately, we can estimate neither the flow of services from durables obtained by households who own durables but do not make a transaction during the sample period nor, for households that engage in a transaction, the consumption of the durable goods owned prior to the purchase of a new good. We suspect that our measure overestimates consumption drops (basically, because we assign a zero to pre-purchase consumption of durable goods). Summary statistics of those variables are shown in Tables 2 and 3.

Table 7 reruns the results in Table 5, now using our corrected measure of expenditure. The WLS results in rows 1 through 3 of Table 7 are qualitatively consistent with those in Table 5, but the magnitude is of course much lower (for the 46-55 group, we estimate a drop in our consumption measure of 3.3\%). For the rest of the groups, we do not detect a significantly different from zero drop in expenditure once we distribute expenditures in durables among periods.

The second panel in Table 7 documents the evolution of the level of periodified expenditure around the introduction of the tax incentives. The average expenditure drop in the 46-55-year-old group is about 72 euros, standard error: 40 euros. We find positive effects for the age groups of 56-65 and 36-45.

Columns 2-4 of Table 7 provide an informal assessment of the extent of new saving by age group within the top quartile of the family earnings distribution. Column 2 presents the drop in consumption estimated in Table 7, column 1 relative to the control group, as estimated in Panel A of Table 7. In column 3, we document the unconditional average contribution by each group minus the contribution of the control group. The estimates in column 1 are obtained subtracting magnitudes in row 1 of Table 4 . For example, the estimated drop in consumption in the log specification for the 36 to 45 age group (relative to 20-35), is presented in row 1 of column 3 and is 19 euros. On average, the 36-45 age group contributed 62 euros more than the 20-35 years of age group, yielding an estimate of increased saving of 31 cents per euro contributed. As for the group between 46 and 55 years of age, they contributed 119 euros more than the 20-35 years of age group, and their consumption fell by 77 euros. In the 46-55year-old group, 64 cents of new saving were created per euro contributed. Possibly, the most surprising result is that in row 1 . The contributions of the group that most actively contributed (top income quartile, ages between 56 and 65) represented no new

\footnotetext{
21 The problem would be solved with either a sufficiently long panel of household expenses or with detailed information about the stock of durables. While the ECPF is one of the longest comprehensive consumption data sets available, it only follows households for up to 2 years. Furthermore, the ECPF contains little information about wealth stocks.

22 Our procedure amounts to multiplying 0.165 to the observed total payment for a car, 0.1179 to the cost of furniture, 0.165 to expenditures in white goods and 0.1833 for electronic goods like a TV or a radio. We obtain those estimates from Fraumeni (1997), who in turn obtains the estimates from Hulten and Wykoff (1995). See Bover (2005) for an application to Spanish data.
} 


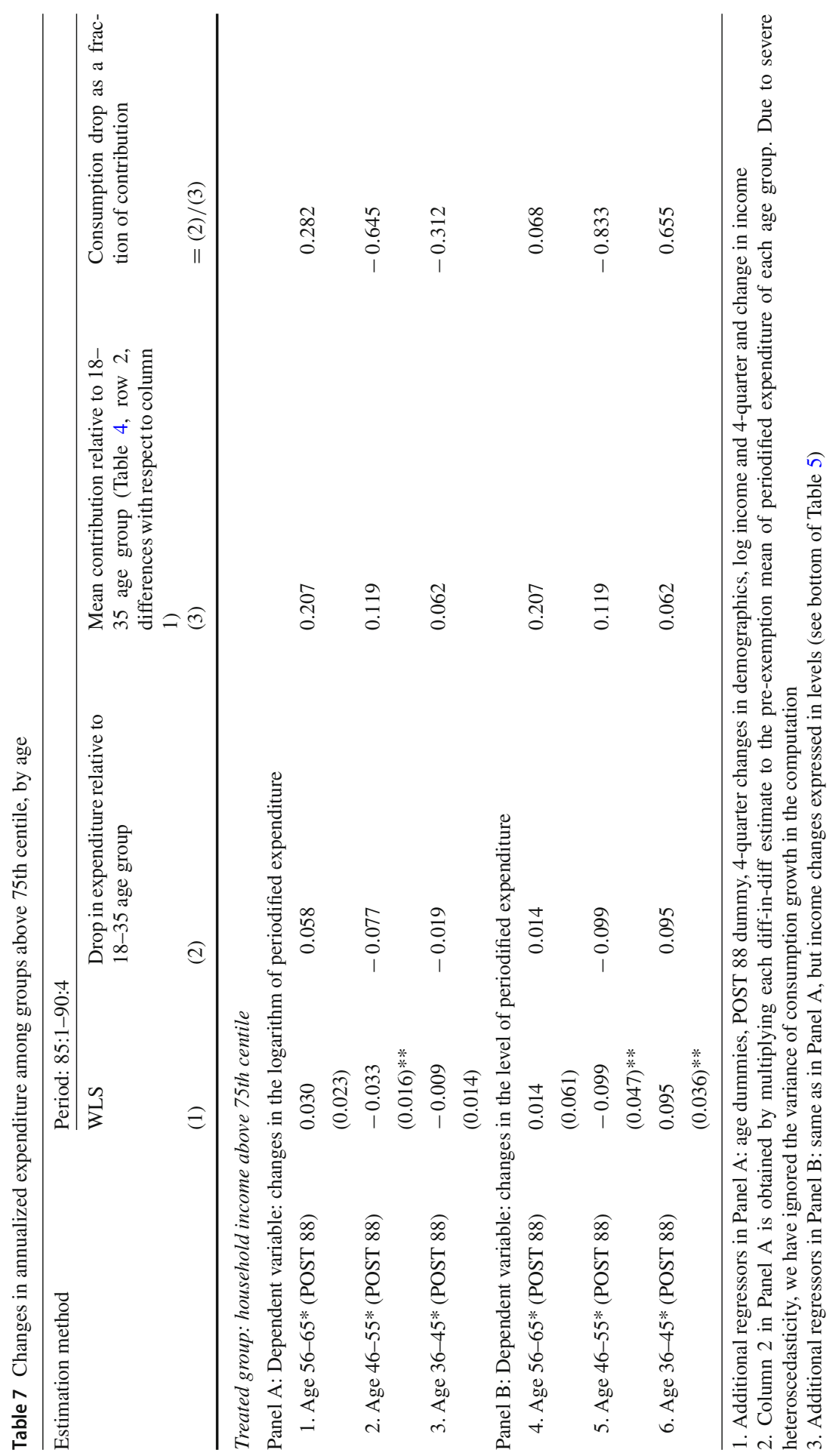


Table 8 Household contributions to pension funds by age and income group, Encuesta Financiera de las Familias 2014. Source: Encuesta Financiera de las Familias 2014, sample of households whose reference person is an employee. Monetary magnitudes in 1000 euros of 1987

\begin{tabular}{llll} 
(1) & $(2)$ & $(3)$ & $(4)$ \\
Age 20-35 & Age 36-45 & Age 46-55 & Age 56-65 \\
\hline
\end{tabular}

Panel A: Gross annual labor earnings in the top quartile of the EFF2014
1. Amount contributed (includes $0 \mathrm{~s}$ )
0.105
0.145
0.401
0.919
2. Percentage households that contribute
0.204
0.287
0.509
0.517
3. Contribution/taxable income (if positive)
0.015
0.019
0.026
0.035
4. Exhausts limit?
0.000
0.000
0.008
0.307

Panel B: Gross annual labor earnings in the second-to-top quartile in the EFF2014

$\begin{array}{lllll}\text { 5. Amount contributed } & 0.013 & 0.091 & 0.103 & 0.335 \\ \text { 6. Percentage households that contribute } & 0.058 & 0.252 & 0.320 & 0.359 \\ \text { 7. Contribution/income (if positive) } & 0.008 & 0.027 & 0.021 & 0.040 \\ \text { 8. Exhausts limit? } & 0.000 & 0.000 & 0.000 & 0.057\end{array}$

Panel C: Gross annual labor earnings in the bottom half of the EFF2014

$\begin{array}{lllll}\text { 9. Amount contributed } & 0.001 & 0.028 & 0.058 & 0.079 \\ \text { 10. Percentage households that contribute } & 0.001 & 0.127 & 0.187 & 0.192 \\ \text { 11. Contribution/income (if positive) } & 0.029 & 0.026 & 0.032 & 0.044 \\ \text { 12. Exhausts limit? } & 0.000 & 0.000 & 0.000 & 0.000\end{array}$

1. Each household contributes an observation. Contributions in rows 1 and 3 aggregate contributions of the reference person and the couple The exception is row 4 (exhausts limits) that takes value 1 if the reference person contributes and exhausts the limit (10,000 euro up to age 50, 12,500 afterward) and 0 if the reference person contributes and does not exhaust the limit

2. Sample partitions were according to the sum of pre-tax household earnings quartiles in 2013 of the reference person and the couple in 2013

saving at all and most likely came from portfolio reshuffling. In Panel B of Table 8 we present broadly similar results using the level of the consumption drop as the dependent variable.

A more formal, but perhaps less informative way of summarizing the degree of new saving created by the pension plans program is to look at Two-Sample Two-Stage Least Squares. ${ }^{23}$ Those estimates are presented in Table 8 . The first column is the first-stage equation that predicts contributions to pension plans using the age group and income quartile of the main filer at the time of the introduction of tax incentives, and restrict-

\footnotetext{
${ }^{23}$ Namely, we use the following procedure. We use the subsample of households in the panel of tax returns who report incomes in the top two quartiles of the ECPF distribution of pre-tax earnings. We regress contributions (including zeroes) on the following variables: age dummies, year dummies, a dummy the level of pre-tax household earnings, household composition variables (dummies for one, two, three and more than four descendants, a dummy for the presence of an elderly of more than 65 years of age and the total number of members). We also include 1-year change in all variables but age. We use OLS to predict average contributions, but average predictions of contributions do not change much when we use a Tobit model to obtain predictions. We then use the imputed contribution in an OLS regression of the change in the level of consumption on the same set of covariates listed above. Note that we identify the model by not including in the consumption regression an interaction between top income quartile, age group and POST 88 dummy. Two final notes regarding the computation of the standard errors. We have used Weighted Least Squares to estimate the models in Table 8, where the observation-specific weights come from the inverse of the OLS
} 
ing taxpayers to those who were in the top two quartiles of the income distribution that year. The interactions between age dummies, top income quartile (and POST 88 dummy) in column 1, rows 2-4 are significantly different from zero at any conventional significance level. The TSLS estimate is presented in the second column of Table 8, row 1 and is $-0.054(0.155)$. While imprecise, the result suggests that each additional euro of contributions reduces consumption by a marginal amount. Columns (3) and (4) include an additional control variable dummies indicating the income bracket the household. ${ }^{24}$ The corresponding TSLS estimate is somewhat larger and suggests a consumption drop of 12 cents per euro contributed. Finally, columns (5) and (6) introduce dummies for the labor status of both members of the couple and its interaction with a POST 88 dummy, resulting in a consumption drop of 19 cents, suggesting a larger consumption drop than the previous estimates. As we discussed above, those average estimates conceal substantial heterogeneity across age groups.

\section{Contributions to pension plans in 2014}

Obtaining an estimate of how much new saving are pension plans generating today is beyond of the scope of this paper. However, as the distribution of contributions at the time of introduction offered some keys to understand the effectiveness of the program, it is useful to analyze the distribution of contributions to pension plans by age and income as of 2014. This section uses the 2014 wave of the Encuesta Financiera de las Familias (EFF) to do that comparison. ${ }^{25}$

The take-up of the program among households whose reference person has more than 35 years has increased substantially. In 2014, between 13 and 19\% of households above 35 years and in the bottom half of the distribution of labor earnings contributed to pension plans (Table 8, row 10, columns 2-4). In the top quartile, the fraction of contributors ranges between $30 \%$ within the 36-45 age group and 50\% in the group closest to retirement. Depending on the group considered, the probability of contributing to a pension plan was between 3 and 6 times larger in 2014 than in the 1988-1991 period. On the other hand, among contributors, contributions to pension plans have diminished from around $10 \%$ of earnings to about $3 \%$. As a result, the unconditional amount contributed to pension plans has doubled at the top quartile and experienced fivefold increase at the rest of the distribution (measured in euros of 1987). The volume of saving directed to tax-favored retirement vehicles has then increased substantially between 1988 and 2014.

On the other hand, within the top earnings quartile, the unconditional mean contribution in 2014 was more concentrated in the group aged 56-65 than it was at the

\footnotetext{
Footnote 23 continued

residuals. Standard errors are corrected for heteroscedasticity and arbitrary autocorrelation between the observations of the same household, but not for generated regressors.

24 The brackets included as regressors are, income between 15,000 and 18,000 euro, another one for between 18,000 and 24,000 euro, another one for income between 24,000 and 30,000 euro and a final one for households whose income is above 30,000 euro.

25 We have also used a new version of the Panel of Tax Returns during the period 1999-2013 to cross-check results. The results are qualitatively similar to those in Table 8 and available upon request.
} 
introduction of the program. Households closest to retirement contributed in 2014919 euros to pension plans (Table 8, row 1, column 4), twice as much as the 46-55 group that contributed 400 euro (Table 8, row 1, column 3). The difference between both groups was much less marked in 1988-1991 (see Table 4).

Table 7 documented that contributions to pension plans generated little saving for the group aged 56-65 at the time of the introduction (see Table 7, row 1, column 1). ${ }^{26}$ Assuming that the estimates of the fall in expenditure associated with tax incentives had not changed between 1988 and 2014, the increasing share of contributions by households close to retirement would suggest that the estimates of new saving generated by tax incentives may not be higher than those documented in Table 8 .

However, two notes of caution apply. The first is that the menu of saving and borrowing products available to Spanish households has changed during the last 30 years, as well as the possibility to fund new contributions out of savings. The implications of those changes for the generation of new saving are not clear. ${ }^{27}$ Second, holding pension plans was much more common at the bottom half of the distribution of earnings in 2014 than at the introduction. As the estimates in Tables 7 and 8 are driven by the top quartile of the distribution of earnings, extrapolating that behavior to other groups may not be warranted.

\section{Concluding remarks}

Tax incentives of retirement savings might increase wealth upon retirement by either increasing savings during individuals working lives or by changing the composition of wealth portfolios toward assets that are more likely to be maintained until retirement age, as it is the case of pension plans. The identification of the global effects of tax incentives of retirement saving is blurred by several difficulties, such as the wide heterogeneity in the individual responses, the lack of microeconomic data on consumption, saving, and wealth through the life cycle, and the differential impact that tax incentives may have at the moment when they are introduced with respect a situation in which they have been operative for a long period.

In this paper we have examined the effects tax incentives of retirement savings in Spain in 1988, when they were first introduced. Thus, by using data spanning the periods before and after the introduction of tax-favored retirement plans, we can observe changes in consumption trends among different groups in the population which could be related to contributions to pension plans. For establishing this relationship, we rely on the fact that individuals with higher-income marginal tax rates experiment a higher incentive to contribute to pension plans, while we use age as proxy for income risk and preference for liquid assets, another dimension in which retirement savings differ from other savings.

\footnotetext{
26 A possible explanation for that behavior was the presence of limit contributors in the group aged 56-65 in the top quartile of earnings (30\%). Interestingly, according to the EFF, the share of limit contributors was similar in 2014 (see Table 8, row 4, column 4).

27 On the one hand, the degree of household borrowing has increased substantially, a fact that raises the theoretical possibility of funding contributions by slowing down the repayment of mortgages, say. On the other hand, the tax incentive offered by pension funds may be a more attractive feature in a situation of low interest rates than in other periods.
} 
While the overall amount of new saving we estimate is limited (at most 19 cents per euro contributed on average), saving responses differ substantially across age groups. In particular, we document very small consumption drops among the group of households between 56 and 65 years of age, the group that most actively contributed to the plan, while we find instead a large decrease in consumption expenditures of the group of households between 46 and 55 years of age, where most of the contributions did represent new saving. In our view, these results cast doubts about the effectiveness of these tax incentives to promote retirement savings, specially when compared to the fiscal costs that they have in terms of lost government revenues. Nevertheless, we discuss that a simple extrapolation of the results observed during the introduction of the incentives to the current situation is not warranted. A full assessment of these incentives would require the measurement on its impact on post-retirement wealth and income, a topic that is left for further research.

\section{Compliance with ethical standards}

Conflict of interest All authors declare that they have no conflict of interest.

Human and animal rights Research involving human participants and/or animals: For this type of study, formal consent is not required.

Informed consent Informed consent was obtained from all individual participants included in the ECPF. The study also relies on administrative data made available by public institutions for research purposes where individual-level information has been anonymized.

Open Access This article is distributed under the terms of the Creative Commons Attribution 4.0 International License (http://creativecommons.org/licenses/by/4.0/), which permits unrestricted use, distribution, and reproduction in any medium, provided you give appropriate credit to the original author(s) and the source, provide a link to the Creative Commons license, and indicate if changes were made.

\section{Appendix 1: ECPF sample construction}

We use a sample of 148,679 households-quarters headed by married ECPF respondents between 1985 and 1996. We start by only considering households between 20 and 65 years of age, thus excluding 34,378 household-quarter observations and observations before 1992 (thus excluding 46,801 cases). We exclude 776 observations of households that reported zero food expenses at home. We also excluded 31,635 observations of households for whom our measure of reported income (incomes from labor, real estate, transfers, other income and irregular income, excluding interest rate income) was either missing or whose primary earner reported monthly net earnings below the statutory minimum wage. A total of 139 observations on households-quarters headed by a retired individual were excluded. A total of 529 observations in which the primary earner is unemployed were also dropped. (The 19/1987 law did not allow those individuals to contribute to a pension plan.) We also excluded 2060 observations of quarterhouseholds who reported self-employment income (including farm income). Those restrictions left us with 32,361 cases that we used to compute year-specific quartiles of the pre-tax earnings distribution (see "Appendix 2" section). We could define 4- 
Table 9 The marginal income tax, by income bracket and the incentive to contribute to pension funds

\begin{tabular}{|c|c|c|c|c|}
\hline \multirow{2}{*}{$\begin{array}{l}\text { Income bracket in } \\
1987\end{array}$} & \multirow{2}{*}{$\begin{array}{l}\text { Cumulative } \\
\text { distribution }\end{array}$} & \multicolumn{2}{|c|}{ Marginal income tax } & \multirow{2}{*}{$\begin{array}{l}\log (1-\operatorname{MTAX87*0.01)} \\
-\log \left(1-\text { MTAX88*0.01) }^{*}\right)\end{array}$} \\
\hline & & 1984-1987 & 1988-1992 & \\
\hline 1 & 13.36 & 8 & 0 & -0.0362 \\
\hline 2 & 16.34 & 16.85 & 25 & 0.0448 \\
\hline 3 & 23.42 & 21.29 & 25 & 0.0210 \\
\hline 4 & 46.46 & 27.2 & 25 & -0.0129 \\
\hline 5 & 55.83 & 33.1 & 26 & -0.0438 \\
\hline 6 & 70.22 & 22.13 & 26 & 0.0221 \\
\hline 7 & 79.95 & 23.74 & 27 & 0.0190 \\
\hline 8 & 85.84 & 25.9 & 28 & 0.0125 \\
\hline 9 & 89.8 & 28.06 & 28 & -0.0004 \\
\hline 10 & 92.4 & 30.22 & 30 & -0.0014 \\
\hline 11 & 94.3 & 32.38 & 32 & -0.0024 \\
\hline 12 & 95.72 & 34.54 & 34 & -0.0036 \\
\hline 13 & 96.76 & 36.7 & 36 & -0.0048 \\
\hline 14 & 97.52 & 38.86 & 38.5 & -0.0025 \\
\hline 15 & 98.1 & 41 & 38.5 & -0.0180 \\
\hline 16 & 98.53 & 43.18 & 41 & -0.0164 \\
\hline 17 & 98.84 & 45.34 & 43.5 & -0.0144 \\
\hline 18 & 99.09 & 47.5 & 46 & -0.0122 \\
\hline 19 & 99.28 & 51.82 & 51 & -0.0073 \\
\hline $20+$ & 100 & $56.14-65$ & 56 & - \\
\hline
\end{tabular}

Table 10 Do contributors persist contributing? Source: Panel of tax returns (1988-1998). The sample in the second panel only contains observations on filers who report only income as employees

\begin{tabular}{|c|c|c|c|c|c|}
\hline \multirow[b]{2}{*}{ Sample size } & \multirow{2}{*}{$\begin{array}{l}\begin{array}{l}\text { All } \\
\text { employees }\end{array} \\
56,831\end{array}$} & \multicolumn{4}{|c|}{ If MTAX $<2828 \leq$ MTAX $<3030 \leq$ MTAX $<3636<$ MTAX } \\
\hline & & 28,333 & 5767 & 10,281 & 6853 \\
\hline $\begin{array}{l}\text { Contributes } 1 \text { year after } \\
\text { first contribution }\end{array}$ & 0.710 & 0.665 & 0.719 & 0.765 & 0.814 \\
\hline [median contribution] & {$[377.71]$} & [361.44] & [433.73] & [1445.8] & [1237.3] \\
\hline $\begin{array}{l}\text { Contributes } 2 \text { years after } \\
\text { first contribution }\end{array}$ & 0.654 & 0.596 & 0.629 & 0.717 & 0.778 \\
\hline [median contribution] & [361.44] & [400] & [240.96] & [627.42] & [1321.86] \\
\hline $\begin{array}{l}\text { Contributes } 6 \text { years after } \\
\text { first contribution }\end{array}$ & 0.563 & 0.454 & 0.532 & 0.619 & 0.709 \\
\hline [median contribution] & [317.86] & 0 & [180.72] & [526.23] & [1295.57] \\
\hline $\begin{array}{l}\text { Contributes } 8 \text { years after } \\
\text { first contribution }\end{array}$ & 0.525 & 0.392 & 0.548 & 0.599 & 0.707 \\
\hline [median contribution] & [180.72] & 0 & {$[301.2]$} & {$[526.5]$} & [1761.9] \\
\hline $\begin{array}{l}\text { Average \# contributions } \\
6 \text { years after }\end{array}$ & 4.637 & 3.993 & 4.502 & 5.04 & 5.468 \\
\hline
\end{tabular}


quarters ahead differences in household expenditure for 8361 cases. Seventy-five cases exhibited expenditure in quarter $q+4$ that exceeded (were below) by more (less) than 7.38 (0.11) times expenditure in quarter $q$. We dropped such cases. Overall, we have information on 8286 cases (Tables 9, 10 in the Appendix).

\title{
11 Appendix 2: Construction of pre-tax earnings in the expenditure survey
}

The paper uses pre-tax income group to split the sample. There are two reasons for doing this: the tax return sample provides pre-tax labor earnings, and there is a clear link between pre-tax earnings and marginal income taxes. (The variable in turn determines the incentive to use a tax-favored product.) However, the ECPF questionnaire asks for a measure of monthly post-tax labor income (gross income net of contributions to the Social Security System and income tax withholdings). The ECPF staff converts the monthly report into a quarterly one. We constructed measures of pre-tax earnings out of the ECPF labor income measure using four steps (Tables 11, 12 in the Appendix):

Table 11 Average four-quarter log expenditure growth for selected groups, by age and time period

$\begin{array}{ll}\text { Before } 1987.1 & \text { After } 1987.1 \\ (1) & \text { (2) }\end{array}$

Time differences

(1)

(2)

(3)

Panel A: Mean expenditure growth within the top income quartile

$\begin{array}{llll}\text { 1. Treatment group: age 46-65 } & 0.068 & 0.010 & -0.058 \\ \text { 2. Control group: age 20-35 } & (0.050) & (0.030) & (0.041) \\ & 0.011 & 0.083 & 0.072 \\ & (0.046) & (0.038) & (0.058)\end{array}$

$\begin{array}{llcl}\text { 3. Age difference, within period } & 0.067 & -0.053 & -0.130 \\ & (0.061) & (0.041) & (0.076)^{*}\end{array}$

Panel B: Mean expenditure growth within the second-to-top income quartile

$\begin{array}{llll}\text { 4. Control group: Age 46-65 } & 0.025 & 0.045 & 0.02 \\ \text { 5. Control group: Age 20-35 } & (0.040) & (0.031) & (0.045) \\ & -0.005 & 0.050 & 0.055 \\ & (0.051) & (0.034) & (0.084)\end{array}$
6. Age difference, within period
0.031
(0.064)
$-0.002$
$-0.035$
$(0.072)$

D-in-D estimate

\begin{abstract}
1. Each entry in the table is the group average of household-specific consumption growth over four quarters. Each household contributes as many observations as times are observed in the sample. Standard errors clustered at the household level and computed using an OLS regression of household-specific consumption growth on age dummies, period dummies and the interactions between those variables

2. "Before 1987.1" means that the first observation used to compute household-specific expenditure growth is observed before 1987.1. Thus, consumption growth does not include any period after the introduction of the exemption
\end{abstract}


Table 12 Other changes correlated with the reform

\begin{tabular}{llll}
\hline Estimation method & Probit & Probit & Probit \\
Dependent variable & Purchase house & Separate filing & Spouse works \\
Data source & ECPF & Panel tax returns & ECPF \\
Mean dependent variable & 0.0237 & 0.649 & 0.42 \\
All samples are in the top quartile of the distribution & $\begin{array}{c}\text { of labor earnings in the ECPF } \\
(1)\end{array}$ & $(2)$ \\
\hline 1. Age 56-65* (POST 88) & -0.0028 & -0.0015 & 0.0083 \\
& $(0.0142)$ & $(0.0093)$ & $(0.150)$ \\
2. Age 46-55* (POST 88) & -0.0153 & 0.0375 & -0.0157 \\
& $(0.0071)^{* *}$ & $(0.0072)^{* *}$ & $(0.103)$ \\
3. Age 36-45* (POST 88) & -0.0066 & -0.0288 & 0.0363 \\
& $(0.012)$ & $(0.006)^{* *}$ & $(0.0933)$ \\
4. Age 56-65 & 0.013 & & -0.388 \\
& $(0.0182)$ & & $(0.0664)^{* *}$ \\
5. Age 46-55 & -0.0004 & & -0.337 \\
& $(0.0116)$ & & $(0.071)^{* *}$ \\
6. Age 36-45 & 0.002 & -0.23 \\
& $(0.0109)$ & & $(0.072)^{* *}$ \\
7. POST 88 & -0.012 & 0.012 \\
Sample size & $(0.011)$ & & $(0.081)$ \\
\hline
\end{tabular}

Step 1 First, we annualize the quarterly net income report contained in the ECPF. We do this by adding up all the net labor earnings we observe for the individual for each year if the individual is surveyed for four quarters. Otherwise, we convert quarterly income into yearly income by multiplying by the corresponding factor (e.g., 4/3 if the individual is observed in 3 quarters of the calendar year, 2 if the individual is observed in two quarters of the calendar year and 4 if the individual is only observed once in a year).

Step 2 Each year in the sample period, the Spanish law defined a schedule of some 27 brackets of pre-tax earnings $y_{\text {gross }}(i)$, where $i$ indexes the bracket number $=1, \ldots, 27$. The schedule varies with the marital status of the individual and the number of children (if any). There are two deductions out of individual gross income: tax withholdings and social security contributions. First, when gross earnings are between $y_{\text {gross }}(i-1)$ and $y_{\text {gross }}(i)$ and exceed a minimum amount $y_{\text {min_with }}$, employers withhold a fraction of earnings $t_{\text {inc }}(i)$. In addition, a fraction of compulsory contributions to Social Security (typically 6\% during the sample period) is subtracted from pre-tax earnings if they lie between a minimum level of earnings $y_{\min \_s s}$ and $y_{\max \_s s}$. Using those rules, one can define for each value of gross earnings in the grid $y_{\text {gross }}(i)$ a one-to-one corresponding value of "net" earnings $y_{\text {net }}(i)$.

Step 3 We start the following recursion: if post-tax labor earnings $y_{\text {net }}$ falls below $y_{\text {min_ss }}$, we compute gross earnings as $y_{\text {net }}+.06 y_{\min \_s s}$ (during the sam- 
ple period, $y_{\text {min_ss }}$ was below the amount that required employers to withhold taxes). We impute $\frac{y_{\text {net }}}{1-0.06}$ as gross labor earnings if $\frac{y_{\text {net }}}{1-0.06}$ is above $y_{\text {min_SS }}$ but below the amount that requires employers to withhold taxes $y_{\text {min_with }}$. For values of net earnings that correspond to a level of pre-tax earnings that require employees to withhold taxes, the imputed amount of gross earnings is $\frac{y_{\text {net }}-y(i) * t_{\text {inc }}(i-1)+y(i) * t_{\text {inc }}(i)}{1-0.06-t_{\text {inc }}(i)}$.

We do the previous steps for each household member reporting employee labor earnings and then compute household pre-tax earnings as the sum of the earnings of the primary and secondary earners (if one exist).

A set of STATA programs and files with the mapping between gross and net earnings are available from the authors upon request.

\section{References}

Albarrán P (2004) The econometrics of income dynamics and rotating panels, with an application to precautionary saving mimeograph. Universidad Carlos III

Almunia M, Rodríguez-López D (2019) The elasticity of taxable income in Spain. Mimeo

Amromin G, Huang J, Sialm C (2007) The tradeoff between mortgage prepayments and tax-deferred retirement savings. J Public Econ 91(10):2014-2040

Angrist JD, Krueger AB (1992) The effect of age at school entry on educational attainment: an application of instrumental variables with moments from two samples. J Am Stat Assoc 87(418):328-336

Anton JA, Muñoz de Bustillo R, Fernández-Macías E (2014) Supplementary private pensions and saving: evidence from Spain. J Pension Econ Finance 13(4):367-388

Attanasio OP, Brugiavini A (2003) Social security and households' saving. Quart J Econ 118(3):1075-1120

Attanasio OP, De Leire T (2002) The effect of individual retirement accounts on household consumption and national saving. Econ J 112(6):504-538

Attanasio OP, Banks J, Wakefield M (2004) Effectiveness of tax incentives to boost (retirement) saving: theoretical motivation and empirical evidence. OECD Econ Stud 39(2):145-172

Bernheim D (2002) Taxation and saving in A.J. Auerbach and M-Feldstein handbook of public economics edition 1 volume 3. Chapter 18. Elsevier

Bernheim D, Skinner J, Weinberg S (2001) What accounts for the variation in retirement saving across US households? Am Econ Rev 91(4):832-857

Bertrand M, Duflo E, Mullainathan S (2004) How much should we trust differences-in-differences estimates? Q J Econ 119(1):249-276

Beshears J, Choi J, Laibson D, Madrian B (2017) Does front-loading taxation increase savings? Evidence from Roth 401(k) introductions. J Public Econ 151(July 2017):84-95

Blundell R, Preston I (1998) Consumption inequality and income uncertainty. Q J Econ 113:603-640

Blundell R, Emmerson C, Wakefield M (2006) The importance of incentives in influencing private retirement saving: known knowns and known unknowns. The Institute for Fiscal Studies, Working paper 06/09

Bover O (2005) Wealth effects on consumption: microeconometric estimates from the Spanish survey of household finances. Bank of Spain working paper no. 0522

Carrasco R, López-Salido JD, Labeaga JM (2005) Consumption and habits: evidence from panel data. Econ J 115:144-165

Chernozhukov V, Hansen C (2004) The impact of 401(k) participation on the wealth distribution: an instrumental quantile regression analysis. Rev Econ Stat 86(3):735-51

Chetty R, Friedman J, Leth-Petersen S, Nielsen TH, Olsen T (2014) Active vs. passive decisions and crowdout in retirement savings accounts: evidence from Denmark. Q J Econ 129(3):1141-1219. https://doi. org/10.1093/qje/qju013

Chung W, Disney R, Emmerson C, Wakefield M (2006) Public policy and retirement saving incentives in the UK. Mimeo, Nottingham University

Collado MD, Browning M (2007) Habits and heterogeneity in demands: a panel data analysis. J Appl Econ. https://doi.org/10.1002/jae.952 
Duflo E, Gale WG, Liebman J, Orszag P, Saez E (2006) Saving incentives for low- and medium-income families: evidence from a field experiment with H\&R block. Q J Econ 121(4):1311-1346

Engelhardt G, Kumar A (2007) Employer matching and 401(k) saving: evidence from the health and retirement study. J Public Econ 91(10):1920-1943

Engen E, Gale W (2000) The effects of 401(k) plans on household wealth: differences across earnings groups. NBER working paper no. 8032, Cambridge

Engen EM, Gale WG, Scholz JK (1996) The illusory effects of saving incentives on saving. J Econ Perspect 10(4):113-138

Fraumeni B (1997) The measurement of depreciation in the US national income and product accounts. Surv Curr Bus 77:7-23

Gale WG, Scholz JK (1994) IRAs and household saving. Am Econ Rev 84(5):1233-1260

Gelber A (2011) How do 401(k)s affect saving? Evidence from changes in 401(k) eligibility. Am Econ J Econ Policy 3(4):103-122

Gruber J, Saez E (2002) The elasticity of taxable income: evidence and implications. J Public Econ 84:1-32

Hawksworth J (2006) Review of research relevant to assessing the impact of the proposed national pension savings scheme on household savings. Department for Work and Pensions, Research Report No 373

Hulten CR, Wykoff FC (1995) Introductory remarks: issues in the measurement of economic depreciation. Econ Inq 34:10-23

Jappelli T, Pistaferri L (2002) Tax incentives and the demand for life insurance: evidence from Italy. J Public Econ 87:1779-99

López Murphy P, Musalem AR (2004) Pension funds and national saving. Mimeo

Luengo-Prado MJ, Sevilla A (2013) Time to cook: expenditure at retirement in Spain. Econ J 123(569):764789

Milligan K (2002) Tax-preferred savings accounts and marginal tax rates: evidence on RRSP participation. Can J Econ 35:436-456

Poterba JM, Venti SF, Wise DA (1995) Do 401(k) contributions crowd out other personal saving? J Public Econ 58:1-32

Poterba JM, Venti SF, Wise DA (1996) How retirement saving programs increase saving. J Econ Perspect 10(4):91-112

Thaler R (2016) Behavioral economics: past, present and future. Am Econ Rev 106(7):1577-1600

Veall M (2001) Did tax flattening affect RRSP contributions? Can J Econ 34(1):120-131

Publisher's Note Springer Nature remains neutral with regard to jurisdictional claims in published maps and institutional affiliations. 